

LOCKE STUDIES

Vol. 16

https://doi.org/10.5206/ls.2016.654 | ISSN: 1476-0290

Originally published: 2016

Published online: 10 FEBRUARY 2018

(C) Locke Studies, 2016

\title{
Physica in John Locke's Adversaria and Classifications of the Branches of Knowledge
}

\author{
GIULIANA DI BIASE (GABRIELE D’ANNUNZIO UNIVERSITY OF PESCARA)
}

Recommended citation:

Di Biase, Giuliana. "Physica in John Locke's Adversaria and Classifications of the Branches of Knowledge." Locke Studies 16 (2016): 69-165. https://doi.org/10.5206/ls.2016.654

For more information about this article:

https://ojs.lib.uwo.ca/index.php/locke/article/view/654

Locke Studies is published by The John Locke Society.

This is an open access article published under the terms of the Creative Commons AttributionNonCommercial-ShareAlike 4.0 International license, which permits use, distribution and reproduction in any medium, provided the original work is properly cited and shared under the original license. 


\title{
PHYSICA IN JOHN LOCKE'S ADVERSARIA AND CLASSIFICATIONS OF THE BRANCHES OF KNOWLEDGE $^{1}$
}

\author{
GIULIANA DI BIASE
}

\begin{abstract}
The framework of the various schemes of Physica in Locke's classifications of knowledge ( $c a$. 1670-1687) shows relevant traces of what may be defined, in a very broad sense, as an Aristotelian model: the internal divisions of this science are shaped into the classical ordering of the Stagirite's physical works, as was common in seventeenth-century Aristotelian texts on natural philosophy. However, Locke's schemes are also evidence of his uneasiness with that model, especially with reference to the first part - the one containing the fundamentals of physics, or physica generalis - and the last, concerning the objects of senseone of the branches of physica specialis. This uneasiness was clearly due to Locke's adherence to mechanism (in particular to Boyle's mechanism) as well as to his empiricism. The last scheme of Physica (ca. 1687) shows Locke's detachment from the Aristotelian model and his adhesion to Pansophism: the object of physica generalis, which in the earlier schemes was circumscribed to the material world, is re-conceptualised in broader terms which include spiritual beings. This later scheme is also evidence of a redefinition of Physica as a theoretical science, a point which was somewhat obscured in Locke's previous schemes by the location of the discipline after the practical sciences. The various adversaria Locke wrote in 1677 help to illuminate his way of conceiving the object and scope of Physica; they show the relevance he attributed to the Baconian method of natural history, as well as the priority he assigned to useful knowledge with respect to speculative knowledge.
\end{abstract}

\section{\$1. Introduction}

Locke's classifications of the branches of knowledge represent an important source of information about his theological, metaphysical, political, moral and scientific views and their development throughout time - and not only this. They illustrate how Locke conceived the world he lived in, his changing

${ }^{1}$ I would like to thank the reviewers of both this article and a previous one, 'Theologia, Ethics and Natural Law in Locke's Classifications of Knowledge and Adversaria', which appeared in Locke Studies 14 (2014): 177-237. Their precious comments and insights helped me to penetrate the world of Locke's classifications. 
attitudes towards the increasing complexity of the mundus intelligibilis and the strategies he adopted to deal with it. A moderate openness towards novelties, balancing conservatism with a total rejection of past legacies, is the peculiarity of Locke's classifications: the Aristotelian Scholastic worldview, which he had deeply absorbed through his studies at Christ Church, Oxford, is only partially overcome, in the attempt to preserve an equilibrium (a quest for an intellectual via media or mediocritas, the measure which Locke prescribed to the human intellect in the Essay).

The schemes of Politia and Prudentia, the practical sciences, are those which illustrate Locke's conservatism most plainly: their Scholastic content remains almost unaltered in the various classifications, ${ }^{2}$ which is symptomatic of his considering that tradition as insuperable in this regard. As for the schemes of Theologia, the strong influence of puritanism which becomes visible from 1681 does not alter the Scholastic framework of the discipline overall, whereas the exclusion of Metaphysica from the last classification (c. 1687) shows the distance Locke had progressively taken from some aspects of that tradition. The introduction of two new disciplines, Historia and Semiotica, in the classification of 1681 is evidence of his awareness of the growing complexity of knowledge in his time; the grouping of all the disciplines into two branches in the last classification highlights a different purpose, to reconcile this complexity in a superior unity (a pansophic ideal reminiscent of the Scholastic unitas scientiae).

The schemes of Physica better illustrate the complex dialectic of conservativism and openess towards novelties. They clearly show the influence of the Aristotelian tradition, both in their way of conceiving the internal divisions of the science and in the terminology adopted. Locke's physics was based on empiricist epistemology; the rise of empiricism was deeply influenced by

${ }^{2}$ See G. Di Biase, 'The Development of the Concept of Prudentia in Locke's Classification of Knowledge', Society and Politics 7, 2 (2013): 85-125. 
Aristotelianism. The basic interests of British empiricists such as Francis Bacon, William Harvey, Thomas Hobbes, Robert Boyle and Locke himself (the problem of the sources of knowledge, the problem of method and nominalism) illustrate their debts to British Aristotelians, whose peculiar preoccupation was the paramount role attributed to sensation and induction in the context of an attempt to elaborate a method for scientific knowledge. Also those natural philosophers, such as Bacon, who were not favourable to Aristotle in their search for a scientific method, upon closer examination show their debt to Aristotelians such as Kenelm Digby, Edward Brerewood and Robert Sanderson. ${ }^{3}$

Numerous Aristotelians were active in Oxford, where Locke spent the years of his early intellectual formation. Aristotelianism was professed by logicians and philosophers, as well as by physicians such as Harvey. The tantalizing contrast between the old and the new - the academic Aristotelian Scholastic orthodoxy of the schools and the unofficial new philosophy of the 'Invisible college' - was particularly apparent in Oxford in the second half of the seventeenth century: the new conception of matter, space and time characteristic of the new philosophy was markedly antiAristotelian. Nonetheless, as Seth Ward shrewdly observed in his Vindiciae Academiarum (1654), the universality of the problems raised by Aristotle, as well as the concision of his methods, rendered his philosophy pervasive in university courses even though its truth or infallibility was no longer to be assumed. ${ }^{4}$

Aristotelian philosophy formed the core of education in Oxford and in all English universities and colleges throughout the seventeenth century. Aristotle's philosophy of nature was the model to which almost all the textbooks on natural philosophy

${ }^{3}$ See M. Sgarbi, The Aristotelian Tradition and the Rise of British Empiricism (Dordrecht, 2013).

${ }^{4}$ S. Ward, Vindiciae Academiarum Containing, Some Briefe Animadversions Upon Mr Websters Book, Stiled The Examinations of Academies (Oxford, 1654), 39. 
conformed. ${ }^{5}$ The most influential ones were those by the Germans Heinrich Alsted, Johannes Combach, Marcus Friedrich Wendelin, Clement Timpler, Johannes Magirus, Christoph Scheibler, Daniel Sennert and Johannes Stier, the French Eustache of St. Paul, the Spanish Rudolph Arriaga and Francis Oviedo, the Dutch Franck Burgersdijck and Gilbert Jacchaeus, the Italians Giulio Pace and Raffaele Aversa, the Danzig scholar Bartholomew Keckermann, the Danish Caspar Bartholin, and the Englishmen John Case and Robert Sanderson. ${ }^{6}$

To label these authors' works as Aristotelian is potentially misleading: their knowledge of the Aristotelian tradition was derived, in large part, not from medieval commentators but from fifteenth-century authors such as Giulio Cesare Scaligero, Philip Melanchthon, Jacopo Zabarella and the Spanish and Portuguese Jesuits (Francisco de Toledo, Benedict Pereyra, the Conimbricensian commentators and Francisco Suárez), who were those more frequently cited. Besides, their works showed a considerable receptivity to recent discoveries. References to Copernican theory were quite common, ${ }^{7}$ and the framework highlighted the influence of mathematics in the tendency to

${ }^{5}$ See M. Feingold, 'Aristotle and the English Universities in the Seventeenth Century: a Re-Evaluation', in European Universities in the Age of Reformation and Counter Reformation, ed. H. Robinson-Hammerstein (Dublin, 1998); W. Costello, The Scholastic Curriculum at Early Seventeenth Century Cambridge (Cambridge, MA, 1958); S. Morison, Harvard College in the Seventeenth Century, volume 1 (Cambridge, MA, 1936); E. G. W. Bill, Education at Christ Church Oxford, 1660-1680 (Oxford, 1988).

${ }^{6}$ A detailed description of the peculiarities of these authors' works on natural philosophy is supplied in P. Reif, 'The Textbook tradition in Natural Philosophy 16001650', Journal of the History of Ideas 30 (1969): 17-32, to which I am deeply indebted.

${ }^{7}$ A few examples may suffice: in his Enchiridion Physicum (1625), Bartholin quoted directly from Copernicus, and in his Collegium Physicum (1637) Burgesdijk admitted that, with the aid of the telescope, many new stars and comets had been seen in the region beyond the moon, although he continued to uphold the incorruptibility of the heavens. The frequent appearance of supra-lunary phenomena had raised serious doubts about the reality of the impenetrable crystalline spheres, leading Arriaga to entertain the view that the planets float in empty space in his Cursus Philosophicus (Paris, 1639). 
arrange subject matter after the fashion of a geometrical treatise, with axioms, corollaries and scholia. Nonetheless, there was a considerable distance between the textbook content and the new approach to nature typical of the new philosophy, which had evolved for the most part outside the universities. What was absent was the Baconian vision and Galileian practice of using knowledge to gain control over the forces of nature. In contrast to the new scientists, Aristotelian textbooks insisted on the wholly speculative character of natural philosophy, whose utility would ultimately consist in its leading to a greater knowledge and love of God; their assertions could be interpreted as the stubborn resistance of an entrenched academic system to the disturbing encroachments of a new approach upon their world, but also as the strenuous defense of a traditional worldview against destabilizing novelties (a concern incremented by the diffusion of libertinism and pyrrhonism).

Seventeenth-century textbooks on natural philosophy were broadly Aristotelian insofar as they subscribed to Aristotle's theory of nature rather than, for example, to those of the Stoics or Atomists. It was from Aristotle that they took the principal concepts and divisions of the science. In typical Peripatetic fashion, natural philosophy was defined as the speculative science studying the world of changing material things (celestial and terrestrial, animate and inanimate), culminating in the study of man. It was divided into two parts, general and special. Corresponding to Aristotle's Physica, the general part considered the principles and properties common to all natural bodiesmatter and form, quantity, quality, place, time and motion. The special part, on the other hand, dealt with the principles and properties of particular kinds of natural bodies. In its contents, it roughly corresponded to the other Aristotelian works on natural science (De coelo, De generatione et corruptione, Meterologica, De anima, Parva naturalia, De partibus animalium and De generatione animalium). Such a vast programme made seventeenth-century textbooks on natural philosophy a sort of encyclopedia, containing a variegated body of information: the 
beginnings of astronomy, chemistry, meteorology, botany, biology, zoology, physiology, anatomy and psychology were all included. All these different disciplines were considered from a single point of view, that is to say as natural or having an intrinsic principle of change; the aim in both parts - the general and the special — was the same, to attain essential knowledge of natural bodies and their properties, and from these to proceed to the knowledge of species. The difficulties encountered in trying to account for the properties of particular bodies were resolved by recurring to pseudo-explanations such as occult qualities, sympathies, antipathies and the foresight of nature.

No Aristotelian textbooks on natural philosophy were to be found in Locke's library, which may be indicative of his dissatisfaction with them; ${ }^{8}$ by contrast, numerous works of the exponents of the new philosophy were present, even before his leaving for Holland in 1683. ${ }^{9}$ Locke had become acquainted with some of their authors during his first years at Oxford. In the late 1650s he actively took part in experimental research on the physiology of respiration with Robert Hooke, Richard Lower and Robert Boyle. ${ }^{10}$ His knowledge of chemistry, as well as his

${ }^{8}$ The only relevant exception was Sennert's Epitome Naturalis Scientiae: Locke possessed the 1656 edition of Sennert's Opera omnia in two volumes, which included his Epitome ( $L J L$, no. 2617). See note 31, above. As for the other authors above mentioned, Locke possessed a work by Keckermann (Meditatio de insolito et stupendo illo Terrae-motu, LJL no. 1611), another by Bartholin (De diaphragmate \& Jacobaeus de ranis, $L J L$, no. 213) and some works by Sanderson not concerning natural philosophy (LJL, nos. 2547, 2548, 2548a).

${ }^{9}$ In 1681 , Locke possessed eight works by Boyle ( $L J L$, nos. 413, 414, 438, 439, $444,462,465,469)$ seven by Bacon ( $L J L$, nos. 162, 164-166, 169, 175,178), several by Johann Rudolph Glauber ( $L J L$, nos. 1254-1270), two by Francis Glisson ( $L J L$, nos. 1271 and $1272 \mathrm{a}$ ), alongside some works by Petrus Severinus ( $L J L$, no. 2633), Sennert, Galileo ( $L J L$, no. 1208), van Helmont ( $L J L$, no. 1417), Joachimus Jungius ( $L J L$, no. 1593), Descartes ( $L J L$, no. 604), Hooke ( $L J L$, no.1488), Henry Power ( $L J L$, no. 2380), Thomas Willis ( $L J L$, no. 3165a) and Nathaniel Highmore ( $L J L$, no.1451b). See $L J L$, Appendix I, 269-77; A. Clericuzio, Medicina, chimica e filosofia naturale nella biblioteca di John Locke, in Bibliothecae selectae da Cusano a Leopardi, ed. E. Canone (Florence, 1993), 333-75.

${ }^{10}$ See K. Dewhurst, John Locke, Physician and Philosopher (London, 1984), 3-32; P. R. Anstey, John Locke and Natural Philosophy (Oxford, 2011), 52-58. 
practice of it, was deeply influenced by Boyle, whom he had met in 1660. In this year Boyle published his first book, New Experiments physico-mechanicall, touching the Spring of the air, and its effects, which owed much to Torricelli's demonstration of a vacuum in his barometer experiments. Locke's 'weather diary', containing daily recordings of his barometric readings, demonstrated a persistent interest in meteorology sharpened by his intellectual vicinity to Boyle. ${ }^{11}$ The latter was also Locke's main instructor in the application of Helmontian ideas on iatrochemistry, although he had read widely in the works of van Helmont.

The cooperation between Boyle and Locke was particularly intense when the former published The Origin of Formes and Qualities (1666), in which he rejected the Aristotelian idea of matter as continuous, and of individual forms and qualities as being responsible for the differences among the various objects. Boyle's text further developed his corpuscular theory, already formulated in the New Experiments and in The Sceptical Chymist (1661). He supported his theory by laboratory tests - in particular colour dilution tests - which he demonstrated to Locke and which Locke repeated. ${ }^{12}$ The mass of experimental evidence assembled by Boyle in support of his corpuscular philosophy might have gained Locke's general acceptance, in spite of the epistemic skepticism concerning the possibility of proving the truth of corpuscularianism he would go on to express in the Essay. A subsequent, unpublished treatise, Elements of Natural Philosophy, seems to reveal Locke's adhesion to the atomist variant of corpuscularianism, influenced by the reading of Newton's Principia. ${ }^{13}$

${ }^{11}$ Locke's observations, which included the strength and direction of the wind, the atmospheric pressure, the temperature, rainfall, and few general remarks, were later published in Boyle's posthumous A General History of the Air (London,1692: LJL, no. 460), edited by Locke.

${ }^{12}$ Bodl. MS Locke, f. 25, f. 230.

${ }^{13}$ See Locke, Elements of Natural Philosophy (1698), in The Works of John Locke (9 vols., London, 1824, [12 th $^{\text {edn }] .), ~ i i, ~ 413-40 . ~ T h e ~ a t o m i s t ~ v a r i a n t ~ o f ~}$ 
There can be little doubt Locke was well acquainted with Aristotelian textbooks on natural philosophy, which were often used in university courses in his time in substitution of Aristotle's original works. Physica was to be read during the third year at Christ Church, as prescribed by the curriculum; Aristotle's other works on physics and biology were to be read during the fourth year. ${ }^{14}$ Locke might have read the corpus aristotelicum in its entirety, although his library lacks many of Aristotle's works. Nicomachean Ethics, Politics and Rethorics were present, whereas Physica and other works on physics were absent. The presence of a commentary on Aristotle's writings on biology by the Paduan Agostinus Nifus compensated for the absence of the original. ${ }^{15}$

All this reading matter undoubtedly forged Locke's way of conceiving natural philosophy, its object and scope. The great influence which the Aristotelian-Scholastic tradition exerted on his moral, religious and political thought is a further element to be considered ${ }^{16}$ in order to understand why, though siding with the exponents of the new philosophy, Locke continued to employ the Aristotelian terminology of substance and accident in the Essay, which he himself ridiculed. ${ }^{17}$ Likewise, the distinction between

corpuscularianism, as opposed to the plenist variant, rejected the void and claimed the indivisibility of corpuscles. It must be added that recent scholarship has questioned Locke's authorship of the Elements. See J. R. Milton, 'Locke and the Elements of Natural Philosophy: Some Problems of Attribution', Intellectual History Review 22 (2012): 199-219.

${ }^{14}$ See R. S. Woolhouse, Locke: A Biography (Cambridge, 2007), 17.

${ }^{15}$ Augustini Niphi Expositiones in omnes Aristotelis libros De historia animalium... De partibus animalium...Ac De generatione animalium ... (Venice, 1546; LJL, no.117).

${ }^{16}$ See the eulogy of Aristotle- 'a knowing Man'-in An Essay concerning Human Understanding, ed. P. H. Nidditch (Oxford, 1975) [henceforth E], I.iv.23, 101, and compare IV.xvii.4, 671, where he is characterized as 'one of the greatest Men amongst the Antients'.

${ }^{17}$ E I.iv.18, 95: 'since by those ways [sensation and reflection], whereby other Ideas are brought into our Minds, this [the idea of substance] is not, We have no such clear Idea at all, and therefore signify nothing by the word Substance, but only an uncertain supposition of we know not what; $(i . e$. of something whereof we have no particular 
'substance' and 'real essence' (two terms which refer to the same thing in the Essay, the internal constitution of objects and the causal ground of their perceivable properties), ${ }^{18}$ but also the definition of Physica as a speculative discipline and of scientia as a 'certain and universal Knowledge' of the real essences of things and of the necessary connections which flow from them ${ }^{19}$ reveal a certain respect for the abstract structure of Aristotelian philosophy, and for the general intuitions and insights which that structure embodied. Following in the footsteps of Descartes, Gassendi, Boyle and others, Locke attempted to reinterpret and redeploy the terminology and framework of Aristotelian scientific theory, adapting it to both the ontology of mechanism and his anti-dogmatic epistemology. ${ }^{20}$

This same attempt is apparent in the schemes of Physica incorporated in Locke's classifications, where a mechanistic and empiricist view of nature is adapted to an Aristotelian framework. The schemes also reveal Locke's uneasiness with that model, and his final attempt to dispose of it through a re-conceptualization of the object of physica generalis in pansophic terms and the introduction of a new terminology in physica specialis. Nonetheless, the speculative nature attributed to Physica in Locke's last scheme and in the Essay (an aspect which was somewhat obscured, in the previous classification, by its location after practical sciences) seems to indicate his difficulty in abandoning the Aristotelian model completely. In the following section, attention will be drawn to Locke's individual schemes of physics, in order to let their peculiarities emerge clearly; also the

distinct positive) Idea, which we take to be the substratum, or support, of those Ideas we do know'. See also II.xiii.20, 175. The terminology of substance, accident, affection and attribute is almost ubiquitous in the Essay; compare II.xxi.4, 235, where Locke defines the 'sensible Qualities' of sensible things as 'their very Substances'.

${ }^{18}$ E II.xxxi.6, 378-80; regarding the distinction between real and nominal essence, see III.iii.18, 418-19.

${ }^{19}$ E IV.iii.29, 559-60.

${ }^{20}$ See M. R. Ayers, Locke: Epistemology and Ontology (London, 1993), 15-16. 
various adversaria he wrote in 1677 will be considered, though they do not represent, properly speaking, classifications and do not contain any schemes of physics. Nonetheless, several references to natural philosophy in the adversaria render them an important source of information on Locke's way of conceiving the object and scope of the knowledge of nature; the adversaria also shed some light on his schemes of Physica, as we shall see.

\section{\$2. Physica, 1670-1687}

Locke's classifications and adversaria are to be found in his notebooks and journals. ${ }^{21}$ They contain schemes of various disciplines (Theologia, Politia, Prudentia and Physica in the earliest classification, to which Metaphysica, Historia and Semeiotica were added in later ones). The 'Division of the Sciences' on the final pages of the Essay represents the point of arrival of Locke's previous classifications. It appears to be rather sketchy compared with them; perhaps it had been intended as something to be developed, a project Locke dismissed because of the difficulties he encountered in classifying (which seems to be particularly true with reference to the internal divisions of Physica, as I shall attempt to demonstrate).

The first evidence offered by Locke's classifications is that of a marked interest in systematizing and ordering knowledge, a pervasive feature throughout the seventeenth century. The Baconian grand design of an Instauratio Magna, the ambitious encyclopaedic constructions by Andreae, Alsted, Comenius, Caramuel, Izquierdo, Kircher and even Leibniz's pansophic

${ }^{21}$ The manuscripts (a microfilmed copy in the first case, for the original is in Houghton Library, Harvard) are to be found in the Bodleian Library: 'Adversaria 1661', MS Film 77, ff. 1-2, undated; 'Sapientia', MS Locke c. 28, f. 41, dated 1672; MS Locke f. 15, pp. 110, 119-20, 122-23, undated; MS Locke c. 28, f. 50, dated 19 August 1677; MS Locke c. 28, f. 51, dated 12 November 1677; MS Locke f. 2, pp. 247-52, dated 1677; MS Locke c. 42B, p. 22, dated 1679; 'Adversaria 1661', p. 25, undated; 'Adversaria 1661' back endpaper, undated; 'Adversaria 1661', pp. 290-91, dated 1681; MS Locke c. 28, ff. 157-58, undated; MS Locke c. 28, ff. 155-56, undated. The classification on the back endpaper of 'Adversaria 1661' and that in MS Locke c. 42B, p. 22 do not contain any reference to physics, therefore they will not be considered. 
characteristica, which concludes the century, appear to be the expression of a communal intent going beyond confessional differences, to highlight the organic order and unity of all sciences and arts intended as a mirror of the cosmic divine order. The massive use of schemes and diagrams in seventeenth-century syntagma, artes universales, digesta sapientiae, claves doctrinarum and the like was conceived of as a fundamental tool to illustrate the harmonia mundi and the correlated idea of a universal connection and communication between the various sciences (an ideal common both to Mersenne and his adversary Robert Fludd, Descartes and his critics Caramuel and Comenius). The unity and certainty of all human knowledge (the Scholastic metaphysical ideal of a true science of being), was intended as the correlate of the unity and certainty of the divine wisdom and of God's providential design, manifesting itself both in natural phenomena and in human history. ${ }^{22}$

Tables and diagrams showed the pervasive recourse to the dichotomic technique typical of Ramistic dialectics (a technique rooted in the tendency to use spatial models to conceive of the mental and extra-mental world). ${ }^{23}$ The presence of Aristotelian elements, Lullian reminiscences and magical-astronomical symbols akin to those Bruno had introduced in his mnemotecnic writings was also frequent. With the passing of time, schemes and diagrams acquired a predominant role in encyclopaedic writings, becoming their supporting structure. The permanent association between a scheme, an image and a word in Comenius' pansophic writings was evidence of this development, even though the

22 The bibliography on this topic is immense, therefore I only refer to a few pioneering works: W. E. Peuckert, Pansophie. Ein Versucht zur Geschichte der schwarzen und weissen Magie (Stuttgart, 1936); P. Rossi, Clavis universalis. Arti mnemoniche e logica combinatoria da Lullo a Leibniz (Milano-Napoli, 1960); G. H. Turnbull, Hartlib, Dury and Comenius (London, 1968); C. Webster, The Great Instauration, Science, Medicine, and Reform, 1626-1660 (London, 1975); C. Vasoli, L'enciclopedismo nel Seicento (Napoli, 1978).

${ }^{23}$ See W. J. Ong, Ramus, Method and the Decay of Dialogue (Cambridge, MA, 1974), $74 \mathrm{ff}$. 
major encyclopaedias of the beginning of the century, in particular Alsted's, already showed the basic importance attributed to these tools.

The encyclopaedic ideal of a universalis sapientia was also embraced by those seventeenth-century English scientists engaged in the project to create a universal form of language. This task was enthusiastically taken up by a number of eminent members of the Royal Society including John Wilkins, Robert Boyle, Robert Hooke and Newton, for whom the idea of a universal language was a rational response to the perceived inadequacy of seventeenth-century scientific language. ${ }^{24}$ They conceived the analysis of nature through its simple elements to be a fundamental prerequisite for the creation of a philosophical language. Constructing a new system of signs meant providing a model or theory of nature, and the model they adopted was essentially taxonomic.

Taxonomy was a method growing out of the Aristotelian tradition. It rested on a philosophical view of nature originally articulated by Aristotle, including the belief that natural phenomena are comprised of essences which manifest themselves through the genera and species of things. Clearly, essentialism was incompatible with mechanistic philosophy: the language of the latter was mathematics, not taxonomy. Nonetheless, both mathematics and taxonomy could be perceived as images of order - both were attempts to represent the system and order of nature. ${ }^{25}$ This explains why, in spite of his rejection of the more mystical Aristotelian notions of form, Bacon's scientific philosophizing continually took the form of taxonomy, and why both Descartes and Newton attempted to elaborate philosophical language schemes.

${ }^{24}$ See M. Slaughter, Universal Languages and Scientific Taxonomy in the Seventeenth Century (Cambridge, 1982).

${ }^{25}$ Regarding the universal search for order which characterized seventeenth century science, see M. Foucault, The Order of Things: An Archaeology of the Human Sciences (London, 1970), 71ff. 
With respect to encyclopedic and taxonomic schemes, Locke's classifications appear to express a more modest intention. He neither attempted to introduce a new philosophical terminology nor to devise complicated dichotomous structures capable of illustrating all knowledge in detail or showing its organic unity. More simply, the various branches of knowledge were disposed in Locke's classifications in parallel vertical columns, with their names being used as headings to which a series of topics, distinguished in subheadings and subordinated items, were appended. The different disciplines were linked together by a few cross-references formulated through verbal clauses, without employing any marks or symbols. This simplicity was evidence of a personal, perhaps pedagogically-oriented need for order, rather than the intention to engage in scientific enterprise. 'A great help to the memory and means to avoid confusion in our thoughts [Locke affirmed in a journal note for March 6 1677, entitled 'Study'] is to draw out and have frequently before us a scheme of those sciences we employ our studies in, a map, as it were, of the mundus intelligibilis'. ${ }^{26}$ His classifications were probably conceived of in this spirit; that is to say, as maps of studies, not as prospective repositories of all human knowledge.

The schemes of Physica included in the classifications are particularly illuminating in this regard: it would be hard to infer Locke's great interest in botany, zoology, geography and even in medicine from the few topics present in them. Besides, Physica always occupied the last place, being placed after the practical sciences (Politia and Prudentia). Only in the last classification and in the 'Division of the Sciences' at the end of Essay did this location change. The postponing of Physica, a speculative science, to practical sciences was incompatible with Aristotelianism, but was in keeping with the hierarchy of duties (religious; moral; particular obligations linked to one's personal calling) which Locke introduced in 'Study': his intention when

${ }^{26}$ Printed in The Life of John Locke: with Extracts from his Correspondence, Journals and Common-place Books, ed. P. King (2 vols., London, 1830), i, 198. 
penning his classifications was to devise a hierarchy of studies grounded in the demands of Christian duty rather than their relative epistemic status, a disciplinary map subserving the types of study worthy of a Christian philosopher.

The position of Physica in Locke's earlier schemes was also symptomatic of the modification the discipline was undergoing in the second half of the seventeenth century, when a new distinction between experimental and speculative philosophy affirmed itself in the context of the study of nature. The distinction referred to different methods of acquiring knowledge: experiment and observation were the marks of the new philosophy, in contrast with the more speculative approach still prevailing in universities. The mention of several mechanical arts in Locke's schemes is a clue to his desire to echo Bacon's emphasis upon the empirical dimension of physics.

The internal divisions of the science in Locke's schemes of Physica were modelled on the classical ordering of Aristotle's works on physics. However, upon closer examination, the distance he travelled from the Aristotelian model becomes ever more apparent. The first section of the schemes, containing the fundamentals of the science (physica generalis, corresponding to Aristotle's Physica) was the one which underlined this distance most plainly; but the last section, concerning sense objects (one of the branches of physica specialis), was no less illuminating in the same regard.

\subsection{Scheme 1. Physica in Bodleian MS Locke Film 77, ff.1-2}

The title Locke assigned to his earliest scheme of physics (henceforth Scheme 1), ${ }^{27}$ was Physica sive Corporum Scientia. Several seventeenth-century authors-Magirus, Stahl and Burgesdijick, for instance-defined physics as the science investigating corpora naturalia; the absence of the adjective

${ }^{27}$ The classification including the scheme is undated, but was probably written around 1670: see J. R. Milton, 'The Dating of 'Adversaria 1661', The Locke Newsletter 29 (1998): 105-117. 
naturalium in the title of Scheme 1 might represent an intentional omission, for it could imply that there were also non-natural, spiritual bodies. Henry More's theories about the Spirit of Nature (an incorporeal substance extended in space, actuating matter as an emanative cause and representing the Vicarious Power of God' upon the world), ${ }^{28}$ were possibly what Locke intended to distance himself from, perhaps because of the criticism which More had addressed to Boyle: in his Divine Dialogues (1668), More rejected a purely mechanical explanation of natural phenomena such as the one offered by Boyle in his Hydrostatical Paradoxes (1666), and resisted any attempt to conciliate mechanism with religion. In his Enchiridion Metaphysicum (1671), More cited Boyle's experiments on hydrostatics as proof of the correctness of his theories; Boyle's answer to More, ${ }^{29}$ though full of tact and respect, demolished the latter's argumentation and demonstrated that the hypothesis of a Spirit of Nature was unnecessary to hydrostatics. The materialistic understanding of nature embraced by Boyle-his 'mechanical' philosophy-deprived matter of any purposiveness and characterized all teleology in nature as the consequence of the external design of a non-material agent. His criticism of Aristotle and the Stoics' notion of nature (as well as of Scholastic natural philosophy) ${ }^{30}$ was directed to this same end, the rejection of any

${ }^{28}$ Henry More, A Collection of Severall Philosophical Writings of Dr Henry More (London, 1662), 46.

${ }^{29}$ Boyle, An Hydrostatical Discourse occasion'd by some Objections of Dr. Henry More (London, 1672). A full account of the controversy between More and Boyle is given in R. A. Greene, 'Robert Boyle and Henry More on the Spirit of Nature', Journal of the History of Ideas 23 (1962): 451-74.

${ }^{30}$ Boyle, A Free Enquiry into the Vulgarly Received Notion of Nature (London, 1685; Boyle was already working on this book in 1666). Scholasticism, Boyle affirmed in the Enquiry, assumed a universe in which a purposive rationality worked quite apart from God and divine providence, and in which there was no distinction between 'nature' and 'providence'; this might lead to some form of 'paganizing naturalism', which must be overthrown. Boyle's strategy was first to show that the Scholastic conception was not scientifically valid, and then to offer his corpuscular philosophy as a superior alternative. 
immanent teleology because of its ascribing to nature creative powers which belonged properly only to God.

Locke's adoption of Boyle's materialistic understanding of bodies was apparent in Scheme 1 as well as in his subsequent schemes (except Scheme 5, as we shall see, and the 'Division of the Sciences'). In particular, as shown by Scheme 2 (1672), Locke seemed to attribute a great authority to Boyle in defining and renewing the content of physica generalis, which is symptomatic of his considering him as a radical innovator in relation to Aristotelian physics.

Under the heading Physica sive corporum scientia in Scheme 1 Locke listed nine subheadings, respectively 'Materia', 'Coelestia', 'Fossilia', 'Vegetabilia', 'Animalia', 'Homo', 'Anima', 'Corpus humanum' and 'Sensus'. The subheadings roughly corresponded to Aristotle's works on natural philosophy: 'Materia' to Physica; 'Coelestia', the four elements grouped under it, and 'Fossilia' to De coelo, De generatione et corruptione and Meteorologica. All the other subheadings apart from the last referred to Aristotle's De anima and to his division of living creatures into plants, animals and human beings (corresponding respectively to anima vegetativa, sensitiva and rationalis). 'Sensus' corresponded to De sensu et sensibilibus (the first of the Parva naturalia). The order of the various sections was almost the same as in seventeenth-century textbooks on natural philosophy, apart from 'Sensus': the manuals usually concluded with a part devoted to the rational soul, in conformity with the Biblical account of creation (man as the last and most perfect of the various species), whereas Locke ended Scheme 1, as well as his subsequent schemes, with a section devoted to sense objects. The order of the subheadings was more respectful of the chronology of Aristotle's works (the composition of $D e$ Anima preceded De Sensu), yet this was not, probably, the reason why he located 'Sensus' last of all. The topics listed under this subheading (more numerous than those located under the others), appeared to be closely linked to the empiricism of the two Drafts for the Essay (c. 1671): the peculiar position of 'Sensus' in 
Scheme 1 may therefore reflect the fundamental basis on which he supposed knowledge of nature to repose, i.e. sensation.

Under 'Materia' Locke introduced 'Extensio et Numerus', 'Motus' and 'Universum'; to extension and number he linked 'Geometria et Arithmetica', to motion 'Mechanica'. 'Universum' was linked to 'Mundus Creatio'. Very little remained of the content of Aristotle's Physica - there was no mention of forms, qualities, continuum, infinity, place and time. The distance Locke opened from the Aristotelian model becomes more apparent when we compare Scheme 1 with the index of one of the more advanced seventeenth-century manuals on natural philosophy, Sennert's Epitome naturalis scientiae, which was in Locke's library. ${ }^{31}$ With reference to physica generalis, in his Epitome Sennert listed several of the topics treated in Aristotle's Physica ('De natura Physica', 'De principiis rerum naturalium', 'De natura et causis', 'De continuo et infinito', 'De loco', 'De tempore', 'De motu'). In his Physicae scientiae compendium, published in 1671 but written at least half a century earlier, Robert Sanderson followed more or less the same pattern, adding 'Vacuum' among the arguments of the general part. When compared with that of Sennert or Sanderson's works, the content of physica generalis in Scheme 1 appears to be intentionally deprived of all those features which could represent a reference to the Aristotelian model.

Extension, number and motion corresponded to some of the primary qualities which Locke would attribute to matter in the Essay; the list of qualities would be much more substantial in the

${ }^{31}$ Locke greatly esteemed Sennert; in a journal note for Feb. 3, 1685, he wrote: 'Sennertus, whom all agree to be an authority, has collected the best passages from ancient and modern writers, and added his own learned and worthwhile observations. His works cover thoroughly everything of any value on the art of medicine which had been written before his time' (quoted in Dewhurst, John Locke, 267). Some lengthy notes Locke took from Sennert's works in 1659 (Bodl. MS Locke f. 18, pp. 28-29, 33, 35-36, 82), especially from his Hypomnemata physica, reveal he was especially interested in his view on generation: he referred to Sennert's 'principium seminale' as a cause of spontaneous generation. 
latter, ${ }^{32}$ and would not give priority to extension. According to Galileo, extension and its modes (shape and size), situation, motion (or rest) and number were the real, objective qualities of matter or corporeal substance, distinct from apparent qualities such as taste, smell, and so forth; ${ }^{33}$ the corporeal domain was limited to the real qualities of matter, which could be described in mathematical terms. Descartes considered only extension to be an essential property of matter; ${ }^{34}$ Walter Charleton took prime matter to be 'absolutely devoid of all quantity', ${ }^{35}$ whilst Hobbes considered extension, quantity, and aptness to receive forma and accidentia as the fundamental attributes of matter. ${ }^{36}$ Boyle's definition of matter in The Origin as a 'substance extended, divisible, impenetrable', endowed with motion by God, introduced the notion of impenetrability, which anticipated Locke's 'solidity'. 37

32 The list Locke would give in $E$, II.viii differs in the various paragraphs; the chapter includes solidity, extension, figure, motion, rest, bulk, number, texture, size and situation. For Locke's treatment of primary qualities, see J. W. Yolton, Locke and the Compass of Human Understanding: A Selective Commentary on the Essay (Cambridge, 1970), 25-27.

${ }^{33}$ G. Galilei, Il Saggiatore (Rome-Padua, 2005), 284-85.

${ }^{34}$ R. Descartes, Principia Philosophiae, in Ouevres, ed. C. Adam and P. Tannery (13 vols., Paris, 1897-1913), viii, [i], 25.

${ }^{35}$ W. Charleton, Physiologia Epicuro-Gassendo-Charltoniana (London, 1654), II, i, 1,88 .

${ }^{36}$ T. Hobbes, Elementorum Philosophiae sectio prima. De corpore, viii, 24, in Thomae Hobbes Malmesburiensis Opera Philosophica Quae Latine Scripsit Omnia, ed. Sir W. Molesworth (London, 1839), 105.

${ }^{37}$ See R. Boyle, The Origin of Formes and Qualities, in The Works of the Honourable Robert Boyle, ed. T. Birch (6 vols., London, 1772), iii, 15. Boyle added posture, order, bulk and texture to the Galilean list of primary qualities, though he considered the first two to be reducible to situation (22); bulk depended on size, whereas texture was a complex quality consisting in the shapes, sizes, and motions of an arrangement of corpuscles. Boyle defined size, shape and motion as the 'three essential properties' of each particle of matter (16), but he seemed also to assign a priority to motion with respect to 'Bulk, Figure, Rest, Situation, and Texture', as 'the Great Agent of all that happens in Nature' (15). Compare E, II.iv, 122-27; II.viii.9, 135. 
To this quality, which was not mentioned in Scheme 1, Locke would attribute epistemic priority in the Essay. ${ }^{38}$ In Draft $B,{ }^{39}$ he declared the defining characteristics of matter to be extension and cohesion, which he characterized as conceptually and ontologically prior to all the other qualities. ${ }^{40}$ Impenetrability (as well as the power of receiving and communicating motion) was presented as a consequence of extension and cohesion. Since there was no mention of cohesion in Scheme 1, we may be inclined to assign it to an earlier stage of the development of Locke's idea of matter. Nevertheless, the great relevance attributed to extension and number in both Drafts suggests a conceptual vicinity with the scheme. In Draft A, extension and number were said to be the ' 2 grande \& universal measures of all things', that is to say those upon which all the others depend and 'in which we seeme to have the most certeine knowledg'. ${ }^{41}$ Extension and number where characterized as the basic objects of mathematical reasoning. The ideas of extension, number and 'perhaps' also the idea of motion, Locke declared in Draft B, are the 'most lasting \& those which are universally found in the minds of every man'. ${ }^{42}$ The three qualities listed under 'Materia' in Scheme 1 might therefore have been chosen not only because of the relevance which Boyle and other mechanistic philosophers attributed to them more or less unanimously, but also because of the universality and certainty which Locke attributed to the

${ }^{38}$ See E III.x.15, 498: 'Matter is but a partial and more confused Conception, it seeming to me to be used for the Substance and Solidity of body, without taking in its Extension and Figure'. On solidity, see E II.iv, 122-27 and II.viii.9, 135.

${ }^{39}$ Locke, Draft B, Drafts for the Essay Concerning Human Understanding and Other Philosophical Writings, vol.1: Drafts A and B, ed. P. H. Nidditch and G. A. J. Rogers (Oxford, 2012), §51, 158.

${ }^{40}$ Locke, Draft B, §94, 209.

${ }^{41}$ Locke, Draft A, $\S 11,22$.

${ }^{42}$ Locke, Draft $B, \S 30,140$. Locke might have not been sure about motion because its perception involved, in his opinion, two or more senses, not just one as in the cases of extension and number. 
corresponding ideas, intended as the basic ingredients of our empirical knowledge of the world. Other details in Scheme 1 suggest a close link with the empiricism of the Drafts: the repetition of extension and number under 'Sensus', to anticipate, recalls one of the main theses of the Drafts, the empirical origin of mathematical concepts. The relevance which Locke attributed to the ideas of extension, number and motion in the Drafts, as the most certain, universal and easily retained, ${ }^{43}$ was probably already clear to him when writing Scheme 1 .

The mention of geometry and arithmetic under 'Materia' conformed to the teachings of mechanistic philosophy, which in accordance with Galileo insisted on the mathematical nature of matter. Arithmetic and geometry were the first two mathematical disciplines of the quadrivium; ${ }^{44}$ in the remainder of Scheme 1, Locke introduced the other two, 'Astronomia'45 and 'Musica', the first linked to the subheading 'Coelestia' and the second to 'Soni' (one of the secondary qualities of matter listed under "Sensus").

As for 'Mechanica', its identification with the scientia motus (as in John Wallis's Tractatus de mechanica, published in 1670), was a recent innovation, for mechanics had traditionally been associated with the science of weights, or statics, as it was by

${ }^{43}$ Locke, Draft B, $\S 30,139-40$.

${ }^{44}$ The works on mathematics which Locke collected in his library during his life were not numerous: he possessed Euclid's Elements (LJL, no. 1073), Jacques Peletier's manual L'arithmétique (LJL, no. 2245a) and Pascal's Traité du triangle arithmetique (LJL, no. 2224). As for English mathematicians, Locke owned Isaac Barrow's Works and Lectiones geometricae (LJL, no. 212 and 212a), Jonas Moore's Mathematical Compendium (LJL, no. 2036) and in particular Joseph Raphson's Analysis aequationum universalis ( $L J L$ no. 2441), containing a defense of Newton's theory of absolute space (De spatio reali, LJL no. 2442).

${ }^{45}$ Like those on mathematics, works on astronomy are not numerous in Locke's library: he possessed Galileo's Opere ( $L J L$, no. 1208, not including the Dialogo sopra i due massimi sistemi), Christian Huygens' Systema Saturnium (LJL, no.1538a) and Cosmotheoros ( $L J L$, no. 1537: the data in this work, concerning the distance of the solar system from fixed stars, were used by Locke in the third chapter of the Elements). A work by Honoratus Faber devoted to Huygens's astronomical observations ( $L J L$, no. 979), and other books by Thomas Streete ( $L J L$, no. 2795), Kaspar Knittel ( $L J L$, no. 1645a) and David Gregory ( $L J L$, no. 1313) were also present in his library. 
Galileo and Descartes. ${ }^{46}$ Locke recorded both the meanings of mechanica in his scheme: the latter was reintroduced under 'Sensus' as the discipline concerning 'Gravitas' and 'pondus' (weight).

The last topic under 'Materia', 'Universum', introduced cosmology, which commonly followed the exposition of the principles of natural bodies in Aristotelian textbooks. In The Origin Boyle had affirmed: "we must consider each body not barely, as it is itself, an entire and distinct portion of matter, but as it is a part of the universe, and consequently placed among a great number and variety of other bodies upon which it may act, and by which it may be acted on, in many ways' ${ }^{47}$ In the Essay, Locke would develop the Boylean idea of a inter-dependence of the various bodies in the 'stupendious Structure of the Universe $^{48}$, insisting on their close interlock as affecting the entire scale of nature, from animals to the simplest elements. He believed in a purposive universe, where the close dependencies between objects in nature (the various steps of the chain of being) were evidence of 'the great Design and infinite Goodness of the Architect'. ${ }^{49}$ The dependence of the material world on the creative act of this supreme Architect was highlighted in Scheme $l$ by the topic linked to 'Universum', 'Mundus Creatio'. 'Creatio' was also the last topic listed under Theologia, the first branch of knowledge in the classification of 1670: physics began where

${ }^{46}$ Galileo aimed at a synthesis of statics and dynamics within a new science of mechanics, but he abandoned this project: see P. Galluzzi, Momento. Studi Galileiani (Rome, 1979), 309 ff.

${ }^{47}$ Boyle, The Origin, in Works, iii, 20.

${ }^{48}$ E IV.vi.11, 587. See also IV.vi, 11.585-87, where Locke gives several examples of the dependencies and relations of bodies upon bodies.

${ }^{49}$ E III.vi.12, 447. Nature has no gaps, insisted Locke: 'the Animal and Vegetable Kingdoms, are so nearly join'd, that if you will take the lowest of one, and the highest of the other, there will scarce be perceived any great difference between them; and so on till we come to the lowest and the most inorganical parts of Matter, we shall find every-where, that the several Species are linked together, and differ but in almost insensible degrees'. 
theology ended, as a means of exploring and verifying the divine order of creation. 50

Under the second subheading, 'Coelestia', Locke listed the four elements, respectively 'Ignis', 'Aer', 'Aqua', and 'Terrestria'. The couple 'Coelestia'-'Terrestria' was reminiscent of the subdivision between the two realms, heavenly and sublunary, in Aristotelian textbooks on natural philosophy. In subsequent schemes, 'Terrestria' would become 'Terra', so that the four elements would be more easily recognizable. Devotion to the four-elements theory was one of the main characteristics of seventeenth-century textbooks on natural philosophy: faced with the attacks of Lorenzo Valla, Gerolamo Cardano, Bernardino Telesio and Gómez Pereira, their authors reacted by reaffirming that the elements were four, though they no longer thought of them as arranged in concentric separate spheres (Sennert, Burgersdijck and Eustache of St Paul were particularly eloquent in this regard). It might seem strange to see the iatrochemist Locke pay obeisance to the four element theory: Paracelsus had already discarded it in favour of salt, sulphur and mercury, and van Helmont had carried out some important revision as well. By distilling blood, Boyle had recovered more than four elements; probably in 1666 Locke was repeating his experiments, as shown by a note he took in his diary. ${ }^{51}$

The presence of the four elements in Scheme 1 is symptomatic of Locke's conceiving the Aristotelian worldview as a useful tool to order and systematize the contents of natural philosophy. He certainly took seriously the recommendation which Boyle addressed to the new philosophers in The Origin, that they should not become embroiled in the many Scholastic disputes regarding

\footnotetext{
${ }^{50}$ Regarding creation see Draft $A, \S 16,31$ : 'When the thing is wholly made de novo i.e. noe part there of did ever exist before as when a new particle of matter doth begin to exist in rerum natura which had before noe being and this we cal Creation'. See also Draft B, §134, 254.

${ }^{51}$ Dewhurst, John Locke, 21.
} 
the number of the elements. ${ }^{52}$

'Aer' was linked to 'Meteora', 'Aqua' to 'Mare', and 'Terrestria' to 'Geographia Physica', a subject of great interest to Locke. ${ }^{53}$ The term 'meteors' was still used in the seventeenth and eighteenth centuries to indicate transitory atmospheric phenomena caused by the interaction in the air of terrestrial vapours or exhalations, and consisting of elemental air, fire or water. The theory established by Aristotle in his Meteorologica remained a touchstone in this regard, as shown by the description which John Harris gave of meteors in his Lexicon Technicum $(1704)^{54}$.

As is clearly shown by his last scheme of Physica (1687), Locke used the term fossilia as synonymous with mineralia, as was common in the scientific lexicon of his time (Boyle, to name only one, treated the two terms as equivalents). Between 1665 and 1666 Locke seems to have been particularly interested in mineralogy, an interest he shared not only with Boyle but also with his fellow student David Thomas. His inquiries 'into the nature of Mineralls' of 1666 duly obtained Boyle's approbation. ${ }^{55}$ Locke possessed the most important works on mineralogy of his own and the previous century, including Georgius Agricola's De

${ }^{52}$ Boyle, Works, iii, 6.

${ }^{53}$ The several works on geography collected in Locke's library suggest a permanent interest in this subject. The library contains both works on geographia generalis (such as those by George Abbot, $L J L$ no. 2a, Pierre d'Avity, $L J L$ no. 157 a, Michel Baudrand, $L J L$ no. 224, Philip Brietius, $L J L$ no. 486, Roger Castlemaine, $L J L$ no. 627b, etc.) and several works on geographia specialis (Christoval Acuna's Relation on Amazonia, LJL no. 16, Nicholas Denys's description of North America, LJL no. 951, Pierre Belon's work on the Levant, $L J L$ no. 259, etc.). A list of all the works on geography in Locke's library is given in $L J L$, Appendix V, 298.

${ }^{54}$ Of course, several aspects of Aristotle's meteorological theory were at the same time objects of controversy: see for inst. Boyle, An Examen of Antiperistasis, in Works, ii, 667.

${ }^{55}$ See Boyle to Locke, June 2 1666, in The Correspondence of John Locke ed. E. S. de Beer (henceforth Corr.) (8 vols., Oxford, 1976-), i, 279. 
re metallica. ${ }^{56}$ In that text the term fossilia was used to refer to all inorganic bodies. Conrad Gessner, Ulysses Aldrovandus ${ }^{57}$ and others similarly failed to distinguish between minerals and the mineralized remains of plants and extinct animals, which they named as lapides figurati and regarded as a lusus naturae. A work by John Woodward (a large collection of fossils and minerals) was probably the most effective in establishing the truth concerning fossils; ${ }^{58}$ however, it was published in 1695 , too late to influence Locke's schemes. His acquaintance with the Danish Nicolas Stensen's Prodromus and with Robert Hooke's Micrographia, ${ }^{59}$ both of which insisted on the organic origin of fossils, may have been the reason for Locke's hesitating to use the term "Fossilia" as synonymous with "Mineralia" in Scheme 5 (1687). His reluctance to introduce new terms, which that same scheme evidences, was, perhaps, another sign of Locke's focus on linguistic clarity and simplicity, a concern expressed explicitly in the Essay. ${ }^{60}$

${ }^{56}$ Agricola, De re metallica libri XII (Basle, 1657; LJL, no. 37). Agricola disliked the distinction between fossils and metals prevalent in his time, which was based on Aristotle's division of inorganic bodies into orycta and metalleuta (respectively, bodies formed by dry and humid exalations); he characterized fossils as bodies whose parts were formed either of the same substance (simple fossils) or of different substances which could be reduced to earth, stone or metal (composite fossils). Metals were therefore to be intended as a sub-group of the fossils; since Agricola, the term fossilium assumed the general meaning of inorganic body.

${ }^{57}$ Locke possessed Gessner's De omni rerum fossilium genere (Zürich, 1565; LJL, no. 1247); as for Aldrovandus, he possessed several works of his on animals ( $L J L$, nos. 53-57), where also minerals and plants were treated.

${ }^{58}$ J. Woodward, An Essay towards a Natural History of the Earth, and Terrestrial Bodies, especialy Minerals (London, 1695; LJL, no. 3179).

${ }^{59}$ N. Steno, Prodromus to a Dissertation concerning Solids naturally contained within Solids (Florence, 1669; the work was translated into English in 1671. See LJL, no. 2767); R. Hooke, Micrographia (London, 1665; LJL, no. 1488).

${ }^{60}$ See E III.vi.51, 471: 'He that hath new Notions, will, perhaps, venture sometimes on the coining new Terms to express them; But Men think it a Boldness, and 'tis uncertain, whether common Use will ever make them pass for currant. But in Communication with others, it is necessary, that we conform the Ideas we make the vulgar Words of any Language stand for, to their known proper Significations (which I 
'Animalia', the fourth subheading, is followed by the names of four species, respectively 'Insecta', 'Volatilia', 'Gressilia', and 'Natantia'. 'Gressilia' was the term typically used in Aristotelian translations to denote animals which walk the earth. ${ }^{61}$ Aristotelian divisions of animals traditionally distinguished between terrestrial and aquatic beasts, though Aristotle himself sometimes seemed to forget or reject this dichotomy. ${ }^{62}$ In his Expositiones, Augustinus Nifus followed this traditional partition, further subdividing terrestrial animals into 'gressilia', 'volucres' and 'insecta'. ${ }^{6}$ Locke, by contrast, preferred to avoid this dichotomy altogether and to classify animals as aerial, terrestrial and aquatic, as he would do in the Elements ${ }^{64}$ and in his various schemes: there the

have explain'd at large already,) or else to make known that new Signification, we apply them to'. It is interesting that Locke applied this linguistic criterion also in his schemes which, as some details suggest (in particular the errors regarding the spelling of Greek terms), where probably not intended to be shown to others.

${ }^{61}$ The term was also in Gessner's Historiae Animalium (Zürich, 1555), which Locke possessed (see $L J L$, no. 1248, which refers to the edition of 1620). Locke seems to have been particularly interested in insects: his library contained some works on insects by Aldrovandus ( $L J L$ no. 54), Thomas Mouffet ( $L J L$, no. 2059) and Jan Swammerdam (LJL, no. 2807). See also the journal note for Sept. 19, 1676, in An Early Draft of Locke's Essay, together with Excerpts of his Journals, ed. R. I. Aaron and J. Gibb (Oxford, 1936), 83. See also Elements, 432, where Locke defines insects as 'a great tribe of animals'. In $E$, II.xxi.55, 270, a nice comparison between men and insects may be found.

${ }^{62}$ Sometimes Aristotle introduced the distinction between terrestrial and aquatic animals, as in the History of Animals 1.1.487a14; sometimes he seemed to refuse the (originally Platonic) dichotomy, preferring to divide animals from the outset into more than two classes (as in History of Animals, 1.1. 487b20, where they are divided into those that walk, crawl, and undulate). See P. Pellegrin, Aristotle's Classification of Animals: Biology and the Conceptual Unity of the Aristotelian Corpus (Berkeley, CA, 1986), 22-28.

${ }^{63}$ A. Niphus, Expositiones, 4. There were, of course, different kinds of division. In his Physicae scientiae compendium, iv, 4, Sanderson divided animals into 'Terrestria' and 'Aquea', and 'Terrestria' into 'Gressibilia' and 'Volatia'. 'Gressibilia' were further subdivided into 'Quadrupedia' and 'Reptilia'.

${ }^{64}$ Locke, Elements, 431-32: 'Brutes may be considered as either aerial, terrestrial, aquatic, or amphibious. I call those aerial, which have wings, wherewith they can support themselves in the air. Terrestrial, are those, whose only place of rest is upon the earth. Aquatic, are those, whose constant abode is upon the water. Those are called 
number of species listed under 'Animalia' would become more substantial, but he consistently avoided the traditional dichotomy, which was an instance of the kind of partition he would censure in the Essay. ${ }^{65}$

No topic was listed under 'Vegetabilia', either in Scheme 1 or in subsequent schemes: only in Scheme 5 would Locke introduce a few topics under this subheading. This might seem strange, given the salient interest in botany which Locke's herbarium, manuscript notes, journal and correspondence make plain. ${ }^{66} \mathrm{He}$ probably considered the subject too vast to be treated in every particular in his schemes. Locke's intention, one surmises, was not to focus on the particular but rather on the general, that is to say, on the order of the various divisions of physics and of the corresponding disciplines. That said, it is also possible that the difficulties of which he spoke in the Essay, of finding a suitable criterion for cataloguing plants into species, were already perplexing him at the time he wrote Scheme $1 .{ }^{67}$

amphibious, which live freely in the air upon the earth, and yet are observed to live long upon the water, as if they were natural inhabitants of that element'.

${ }^{65}$ Locke, E III.vi.12, 447. Concerning the criteria for ranking animals into species, see III.v.13, 436; regarding the difficulty of ranking them, which Locke attributed to our ignorance of the real essence of things, see III.vi.9, 444-45; III.vi.16, 448; III.vi 2627, 453-55. See also Draft A, §2, 8-9; Draft B, §76, 183-84 and Locke's journal note for Nov. 19 1677, printed in An Early Draft, 98-99.

${ }^{66}$ See P. Anstey and S. A. Harris, 'Locke and Botany', Studies in History and Philosophy of Science, Part C: Studies in History and Philosophy of Biological and Biomedical Sciences 37 (2006): 151-71. Locke's library contains the most important botanical works of ancient and modern authors, from Dioscoride ( $L J L$, nos. 973 and 973a) to John Ray ( $L J L$, nos. 2444-48). Renaissance works on botany, such as those by Pietro Andrea Mattioli (LJL, nos. 1939 and 1940) and Bartolomaeus de las Casas (LJL, no. 1680a) are present, though seventeenth-century texts prevail: the botanic catalogues by Jacob Bobart ( $L J L$, no. 360) and Pierre Magnol ( $L J L$, no. 1870), the works on exotic plants by Willem Piso ( $L J L$, nos. 2314 and 2315), Jacobus Bontius ( $L J L$, no. 386), Georg Marcgraf (LJL, no. 1900) and Nicolas Gervaise (LJL, no. 1245) are only some of those which may be found in the library.

${ }^{67}$ See E III.vi.23, 451-52, where he rejected the criterion of propagation as insufficient: 'if the Species of Animals and Plants are to be distinguished only by propagation, must I go to the Indies to see the Sire and Dam of the one, and the Plant 
No topic appeared under 'Homo', the sixth subheading, either in Scheme 1 or in its sequel. In the scheme written in 1681, Locke would subsume the seventh subheading, 'Anima', under 'Homo', so as to render the threefold partition of living creatures ('Vegetalia', 'Animalia' and 'Homo') more easily recognizable. In Scheme 1, 'Anima' was followed by three topics, 'Intellectus, Voluntas et passiones'. Intellect and will corresponded to two of the three Aristotelian faculties of the intellective soul; the third, memory, was not cited in Scheme 1. Reason was usually absent from the list of the mental faculties in late sixteenth-seventeenth century philosophical taxonomies: the faculties cited were the Aristotelian ones. Zabarella followed Aristotle, but noted that other commentators regarded memory as not distinct from the intellect. ${ }^{68}$ Decartes's rule seven in his Discourse on method minimized the role of memory. We may suspect that the absence of this faculty in Scheme 1 was due to the latter's influence, Descartes being mentioned in the Drafts.

Passions were introduced under Prudentia, the third discipline in the classification of 1670 ('In passiones suas imperium'); their presence in Scheme 1 is symptomatic of Locke's medical interest in this subject, nourished by the teachings of his influential masters Thomas Willis and Thomas Sydenham. ${ }^{69}$

'Intellectus', 'Voluntas' and 'Passiones' were followed by a gloss: 'qui pertinere etiam possunt ad Theologiam'. This was a reference to the second subheading under Theologia in the same classification, 'Anima separata'. The dual link between Physica

from which the Seed was gather'd, that produced the other, to know whether this be a Tyger or that Tea?'.

${ }^{68} \mathrm{~J}$. Zabarella, De rebus naturalibus libri XXX (Treviso, 1604, the tenth ed.), 516.

${ }^{69}$ Some notes lent to Locke by Thomas Lower (Bodl. MS Locke f. 19, 1-68, passim), regarding Thomas Willis's Sedleian lectures of late 1661 or early 1662, reported on sudden or violent passions being the cause of nervous distempers, especially in women. Sydenham agreed: see his Epistolary Dissertation (Letter to Dr. Cole, 1681/2), in The Works of Thomas Sydenham (2 vols., London, 1850), ii, 89 and 96. 
and Theologia (the first being introduced by 'Creatio') highlighted the subordination of the first to the second, and contributed to creating a sort of hierarchy between the various disciplines. Also their unity was emphasized. Physica depended on Theologia; Prudentia depended on both Theologia (with reference to its supreme end, eternal happiness), and Physica (with reference to one of its instrumental ends, health). The priority assigned to Theologia seemed not, however, to correspond to Locke's main interests when he was composing his first classification: the topics listed under Physica and Prudentia were far more numerous than those collected under Theologia. Subsequent classifications (in particular, that of 1681) revealed a balancing of interests, with the topics listed under theology becoming more numerous.

'Corpus humanum', the eighth subheading, was followed by 'Medicina' and its three branches, 'Anatomia sive historia partium', 'Pathologia sive historia affectuum' and 'Therapeutica sive historia curationum'. Physiology (closely linked to anatomical research), pathology and therapeutics represented the three fundamental 'Medical Institutions' in the seventeenth century, the three branches of medicina theorica. ${ }^{70}$ The practical side of medicine (Practica) consisted in lists of signs and their corresponding treatments. Locke's expertise encompassed both theoretical and practical medicine, thanks to his studies and experiences in Oxford. His library contained a few ancient and medieval works on medicine (those by Hippocrates mostly, and some exponents of the school of Salerno); ${ }^{71}$ with reference to

${ }^{70}$ Medical theory (Theorica) received formal definition by the middle of the seventeenth-century. Physiology dealt with the conformation of the human body in health (its 'natural' state), pathology was the study of the 'contra-natural' state of the human body. Maintenance of health (Hygiene) and eradication of disease (Therapeutica) represented the third institution.

${ }^{71}$ For Hippocrates, see $L J L$, no. 1457-1457e; Locke also possessed Honoré Bicais's

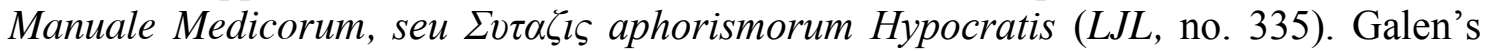
works are absent, apart from the seventeenth-century edition of Leonard Fuchs ( $L J L$, no. 1198a). For the school of Salerno, see $L J L$, no. 2533. 
anatomy, seventeenth-century writings prevailed (those by Harvey, Richard Lower and Jacques Chaillou on blood circulation, those by Thomas Willis, Marcello Malpighi and Gerolamo Fracassati on the anatomy of the brain, those by George Ent, Thomas Bartholin, Malpighi and Swammerdam on respiration, Stensen's treatises on muscles and glands, Glisson's works on the anatomy of liver and of the digestive apparatus, and so on). ${ }^{72}$

As for pathology and therapeutics, Locke's library showed his clear preference for works oriented towards a practical approach. it contained the most important sixteenth-century treatises (such as those by Andrés de Laguna, Felix Plater, Giovan Battista Cortesio, Wolfgang Gabelkover, Timothy Bright and Michele Gavasseti) $^{73}$, as well as several seventeenth-century works (by Henricus de Heer, Lazare Rivière, Santorio Santorio, Petrus Lotichius, Henricus Regius and, in particular, Ludovico Settala, to whom Locke devoted special attention). ${ }^{74}$ The great number of sixteenth and seventeenth century works devoted to practical medicine in Locke's library was evidence not only of his interest in this field (deepened by his medical apprenticeship alongside Sydenham in the years 1667-1670), but also of the progressive

${ }^{72}$ LJL, nos. 1397-1398 (Harvey); 1815 (Lower); 653a (Chaillou); 3165a (Willis); 1888 and 1889 (correspondence between Malpighi and Fracassati on the anatomy of the brain); 1053 (Ent); 215 (Bartholin); 1884 (Malpighi); 2808 (Swammerdam); 27642766a (Stensen); 1272a and 1272b (Glisson). Between 1666 and 1667, Locke composed a treatise entitled Respirationis usus (see J. C. Walmsley, John Locke's natural philosophy 1632-1671, Doctoral Dissert., King's College London, 1998, 262271); in 1668 he penned a short medical essay entitled 'Anatomia' (277-90). Thomas Willis, Locke's teacher at Oxford, was the author of the Cerebri Anatome (1664); among Locke's colleagues at Christ Church, Hooke and Lower were expert anatomists. Locke occasionally planned, and probably also helped to carry out, experiments on animals (see Bodl. MS Locke f. 19, f. 338).

${ }^{73}$ LJL, nos. 1651b-1651d (Laguna); 2331-2331a (Plater); 854 (Cortesio); 1203 (Gabelkover); 487a-488 (Bright); 1222-1222b (Gavasseti).

${ }^{74}$ LJL, nos. 1407-1407a (de Heer); 2486-2487 (Rivière); 2546 (Santorius); 1810 (Lotichius); 2460a (Regius); 2618-2619 (Septalius; Locke took some notes from his work in 1678, found in Bodl. MS Locke c. 33, ff. 3-4). 
overcoming, at the beginning of the seventeenth century, of the traditional distinction between theoretical and practical medicine (whose first union is attributed to Herman Boerhaave). The publication of an increasing number of works on specific topics (particular diseases or parts of the body) corresponded to the decreasing number of works devoted to general medical topics; Sydenham's works on fevers and smallpox, François Bayle and Charles Barbeyrac's on women's diseases, those by Edward Jorden and Nathaniel Highmore on the physiological causes of hysteria, and many others, were present in Locke's library. ${ }^{75}$

Locke's interest in practical medicine was also apparent in the definition of the three branches of medicine as 'histories', a term which recalled Bacon's empirical approach. The empiricism of Baconian philosophy shaped medical thought in the Oxford of Locke's youth, encouraging clinical medicine and direct observation, and disparaging research based upon a priori hypotheses. Bacon urged physicians to study the natural history of phenomena by making a series of specific inquiries, so that the mass of observed facts accumulated throughout a long period of time would lead them to formulate some general explanation. The close dependence of the advancement of knowledge on the compilation of natural histories was frequently insisted on by Locke, ${ }^{76}$ also in the adversaria, as we shall see.

To Aristotle's De sensu corresponded the last subheading in Scheme 1, 'Sensus', which was the most reworked judging by the presence of some deletions. 'Sensus' was followed by 'Objecta sensuum', which introduced the five objects of sense. Each of

${ }^{75}$ Locke possessed two editions of Sydenham's Opera universa (LJL, nos. 28122813), together with his Observationes medicae circa morborum acutorum historiam (LJL, no. 2814), Processus integri (LJL, no. 2815), Schedula monitoria (LJL, no. 2811), Epistolae responsoriae duae de morbis epidemicis (LJL, no. 2816), Opuscula (LJL no. 2816a), and Dissertatio epistolaris...circa curationem variolarum confluentium (LJL, no. 2810). As for Bayle and Barbeyrac's works, see respectively $L J L$, nos. 233 and 200; Jorden and Highmore's works are respectively in LJL, nos.1584 and 1451b.

${ }^{76}$ See E III.xi.24 and 25, 521-22; IV.xii.12, 647. 
them, apart from 'Odores', was linked to one or more artes: 'Colores pictoria et tinctoria'; 'Soni Musica'; 'Odores'; 'Sapores Coquinaria"77; 'Tactiles qualitates Calor frigus et de his omnibus artes mechanicae'. Probably the mechanical arts Locke was thinking of in this last case were those pertaining to husbandry (a subject of great interest for him, as many works in his library, in particular those by Hartlib, suggest), ${ }^{78}$ which were all regulated according to the climate.

The importance attributed to mechanical arts in Scheme 1 conformed to the teachings of Bacon's Novum Organon; it also recalled their appreciation in the Puritan William Ames's Technometria, which listed a great number of them. Both Bacon and Ames had criticized the prejudice surrounding mechanical arts; Ames insisted that there was nothing in them which could be inappropriate for an honest man, or render him less capable of virtuous actions, and that they should be rather considered 'ad societatem privatam et publicam promovendam maximè necessariae'. 79 Ames's Technometria was the science of defining and delineating the arts according to their nature and use. Any art introduced the idea of eupraxia, which existed primarily in God from whom all things emanated. Mechanical arts introduced their own peculiar ideas of eupraxia; only a few of the many listed in the Technometria, which were classified according to the qualitates elementorum (colour, sound, taste and odour) ${ }^{80}$,

${ }^{77}$ Locke's interest in cookery is attested by the presence in his library of a work by François Varenne, Le cuisinier françois (LJL, nos.3051-3051a), one of the most influential cookbooks in early modern French cuisine.

${ }^{78}$ In 1676 Locke composed a treatise on agronomy which remained unedited until 1766, Observations upon the Growth and Culture of Vines and Olives; the Production of Silk; the Preservations of Fruits. His library included De re rustica (LJL, no. 639), which contained the works of Palladium, Cato and Varro; among modern authors, the most frequently found is Samuel Hartlib (A discourse of Husbandrie, LJL, no. 1393; see also nos. 1392, 1394 and 1395). 73.

${ }^{79}$ See William Ames, Technometria, in his Philosophemata (London, 1643), §100,

${ }^{80}$ Ames, Technometria, §114, 93. 
appeared in Scheme 1. Ames's influence was tangible in the outline of Theologia included in the classification Locke wrote in 1681, and he surely shared many of Ames's convictions, especially the priority of the practical over the speculative.

Before the list of objects of sense, 'Numerus Arithmetica', 'Extensio Geometria' and 'Motus', which had already been mentioned under 'Materia', reappeared. 'Motus' was linked to 'Gravitas Pondus mechanica': Locke considered both gravity and weight as secondary qualities of matter, depending on the motion of corpuscles. Gravity was not for him, as for Galileo, Descartes and Newton, an intrinsic property of matter. Galileo believed gravity to be the sole source of motion, yet he was unable to make it the object of his physics because it was unintelligible to him. ${ }^{81}$ Descartes substituted the scholastic account of gravitas as a real quality of a body, which caused it to move towards the centre of the earth, with a purely mechanical account of the phenomenon in terms of the laws of motion and impact and the size, shape and motion of the particles constituting the heavy body and its ambient medium; yet he considered extension to be the only essential property of matter. Descartes and, later, Newton, acknowledged as essential properties of matter only those qualities inherent to a body in some well determined and constant measure, that is, not depending on their variable relation to other bodies. This was not the case with gravity, which implied the interaction of at least two bodies. ${ }^{82}$

In the Essay, Locke considered gravity (or rather the possibility of an unmediated action at a distance between bodies) as one of the phenomena which were too obscure for the corpuscular hypothesis to illuminate, the others being production of sensation, communication of motion and cohesion; the fourth

${ }^{81}$ Galileo, Il Saggiatore, 347.

${ }^{82}$ This was Newton's view when writing the first edition of the Principia in the mid 1680s. See E. Schliesser, 'Without God: Gravity as a Relational Property of Matter in Newton's Treatise' in Vanishing Matter and the Laws of Motion: Descartes and beyond, ed. D. Jalobeanu and P. R. Anstey (London, 2011), 80-100. 
edition of the Essay revealed a shift in opinion, due to his reading of Newton's Principia. ${ }^{83}$ Nonetheless, as Locke's second reply to Stillingfleet made plain, ${ }^{84}$ he continued to regard gravity as too obscure to be explained mechanically, invoking superaddition in its place (an ingredient scarcely conciliable with mechanism, but fully coherent with the pansophic idea of a physics strictly linked to theology which Locke introduced in Scheme 5).

Locke had also written 'Quantitas' and 'Motus' below 'Sensus', separate from the other topics. In Draft A, quantity was said to be synonymous with number if continued, with extension if discreet. ${ }^{85}$ Accordingly we may suppose he had initially thought of avoiding the repetition of extension and number, which were probably added later under 'Sensus' (perhaps at the time he was composing Scheme 2, where 'Extensio' and 'Numerus' were no longer mentioned under 'Materia'). The addition aimed at highlighting the empirical origin of the ideas of extension and number, which Locke considered as the basis of mathematical reasoning. ${ }^{86}$ In Draft $B$, he declared that 'the certein knowledg we have of mathematicall veritys...depends on $\&$ rises from, the certeine destinct knowledg a man hath of the Ideas of his owne minde, $\&$ in this case of those Ideas which he hath at present of several extensions compared i e measured one with an other' ${ }^{87}$ Further on, he referred to the comparison of different

${ }^{83}$ In the first three editions of the Essay, Locke wrote: 'How Bodies operate one upon another...is manifestly by impulse, and nothing else. It being impossible to conceive, that Body should operate on what it does not touch'. (E II.viii.11, 135-36). In the fourth edition, he replaced the claim about how bodies operate with one about how we can conceive of them operating; he also omitted a clause appearing in II.viii.12 of previous editions, that denied unmediated action at a distance.

${ }^{84}$ John Locke, Mr. Locke's Reply to the Right Reverend the Lord Bishop of Worcester's Answer to his Second Letter (1699), in Works, iv, 467.

\footnotetext{
${ }^{85}$ Locke, Draft A, §44, 78.

${ }^{86}$ Locke, Draft B, §26, 137.

${ }^{87}$ Locke, Draft B, $\S 44,152$.
} 
numbers, ${ }^{88}$ once again insisting on the certain knowledge of the corresponding ideas. In Draft A, Locke introduced sight as the sense involved in comparing ideas of different extensions, but he referred also to the comparison between different sounds. ${ }^{89}$ In Draft $B$, he declared that 'how certein soever the knowledg of the equality or inequality of severall magnituds compard is, yet it belongs not soly to extension but all other simple Ideas whose degrees are capable of being measurd', 90 once again he introduced the example of different sounds. The ideas of number and extension were therefore to be conceived as involved in the comparison between all the different sensible qualities.

The mention of extension and number under 'Sensus' (but also that of motion, which Locke considered as an idea deriving from the combined action of different senses), is further evidence of the empiricist perspective which he assumed when writing Scheme 1. This perspective would be maintained in the other schemes with reference to the object of physica specialis; as for physica generalis, which in Scheme 1 hosted the basic concepts of mechanism, its content would be the object of a deep rethinking in Scheme 2, perhaps provoked by Locke's reading of a work Boyle published in 1671. What resulted?

\subsection{Scheme 2. Physica in 'Sapientia 72' (Bodl. MS Locke c. 28, ff. 40-41)}

In the classification Locke wrote in 1672, entitled 'Sapientia', the first part of the scheme of Physica changed significantly. 'Mundus sive Universum' and 'Materia Corpus' were the only

${ }^{88}$ Locke, Draft $B, \S 47,154$.

${ }^{89}$ Locke, Draft A, §12, 23; Draft B, §34, 153-54.

${ }^{90}$ Locke, Draft B, $\S 45, \S 153$.

${ }^{91}$ Locke, Draft $A, \S 8,20$ : 'the minde is funishd with the simple Ideas of things brought in by the sences as of light $\&$ colours by the eys, sounds by the ears, smels by nostrils tasts by the mouth $\&$ palate $\&$ all tangible qualitys by touch, \& some other Ideas from more senses then one as distance $\&$ motion by the eys and touch' . 
items mentioned. The first took the place of 'Materia', which was the subheading under which the various topics pertaining to physica generalis were grouped in Scheme 1. The addition of 'Corpus' seemed intended to compensate for the shortening of the heading (Physica, which substituted Physica corporum scientia of Scheme 1). The postponing of 'Materia Corpus' to 'Mundus sive Universum' suggested the adoption of a different perspective: physica generalis was primarily intended as the discipline investigating the totality of the universe, and secondarily as the study of matter and individual bodies. This change, which represented a detachment from the Aristotelian model, where cosmology followed the exposition of the general principles of natural bodies, might owe something to Locke's reading of Boyle's Systematical or Cosmical Qualities of Things (1671).

As Boyle himself had affirmed, the book represented a development of a subject he had already introduced in The Origin, the reciprocal effects of bodies one upon the other. But while in The Origin the effects taken into consideration were only those impressed on a body by the surrounding ones, the perspective was extended in Cosmical Qualities: what Boyle intended to focus on were 'the impressions that a body may receive, or the power it may acquire from those vulgarly unknown or at least unheeded agents by which it is thus affected, not only upon the account of its own peculiar texture or disposition but by virtue of the general fabric of the world'. ${ }^{92}$ The 'unheeded agents' Boyle named were three: 'the subterraneal parts of the world we inhabit; the stars, whether fixed or wandering, with the aether that is about them; and the atmosphere or air we live in'. However he noted that there were, in addition, 'several grand mundane bodies, and diverse laws and customs of nature which may contribute (more or less) to the phaenomena of the qualities we are treating of'. The peculiarity of cosmical attributes with respect to the qualities inherent to bodies was therefore their dependence upon a vast bundle of relations,

\footnotetext{
${ }^{92}$ Boyle, Works, iii, 307.
} 
linking together the various bodies in 'the grand system or world they are parts of' ${ }^{93}$ The entire universe was crossed by interconnections whose nature and laws were to be inquired into. In the Cosmical Suspicions added as an appendix to Cosmical Qualities, Boyle insisted on the possible communication between the earth, the stars and the interstellar space as a subject worthy of inquiry; ${ }^{94}$ there might be, he reflected, 'some cosmical law or custom of the terrestrial globe, or at least of the planetary vortex ${ }^{95}$ which was responsible for terrestrial phenomena such as tides, new epidemic diseases and magnetic or atmospheric variations, whose nature still awaited clarification. Descartes' three laws of mechanic motion and his seven rules of impact were probably insufficient, in Boyle's view, to account for various terrestrial phenomena:

I have some time suspected [he continued] that there may be, in the terrestrial globe itself, and the ambient atmosphere, divers, whether customs or laws of nature, that belong to this orb, and may be denominated from it, and seemed to have been either unknown to, or overseen by both scholastical and mathematical writers. ${ }^{96}$

Boyle also insisted on the necessity to substitute a mathematical hypothesis of the universe with a physical one: the almost exclusive attention placed by the first on «the magnitudes, situations, and motions of the great globes» was to be implemented by a detailed inquiry into the simple and compound bodies of the terrestrial globe, one of the three agents responsible for the cosmical qualities of bodies.

Cosmical attributes of matter were to be carefully

${ }^{93}$ Boyle, Works, iii, 307.

${ }^{94}$ Boyle, Cosmical Suspicions subjoined as an Appendix to the Discourse of the Cosmical Qualities of Things, in Works, iii, 318.

${ }^{95}$ Boyle, Cosmical Suspicions, 321.

${ }^{96}$ Boyle, Cosmical Suspicions, 319. 
distinguished, Boyle insisted, from magnitude, shape and motion, the 'primitive modes and catholick affections of matter'. 97 These were not relational qualities, and were therefore to be excluded from the investigation. The absence of extension, number and motion from physica generalis in Scheme 2 suggests that Locke had intepreted Boyle's Cosmical Qualities as an invitation to renew the content of theoretical physics, which should primarily focus on the cosmical attributes of bodies and on the 'unheeded relations' upon which they depended. The identity established between 'Mundus' and 'Universum' in Scheme 2 ('Mundus sive Universum', which substituted the 'Universum Mundus Creatio' of Scheme 1) seemed intended to emphasize the Boylean idea of a causal interconnection between terrestrial and celestial phenomena. $^{98}$

The four elements listed under 'Coelestia' were more easily recognizable in Scheme 2, for 'Terra' substituted 'Terrestria'; 'Fossilia' was linked to 'Terra', which became 'Terra et fossilia'. ${ }^{99}$ The initial deletion and subsequent rewriting of

${ }^{97}$ Boyle, Cosmical Qualities, 306.

98 The identity established between 'Mundus' and 'Universum' seems to be a rejection of the Stoics' theory, according to which the two terms were not synonymous: the first one corresponded to the finite world, whereas the second included both the latter and the totality of the infinite void space. In the Drafts, Locke did not take a neat position on the plenist-vacuist debate and it is doubtful that the locution 'Mundus sive Universum' should be interpreted as a rejection of vacuism. Rather, Locke might have been thinking of solving the ambiguity which Boyle registered at the beginning of his Cosmical Suspicions, (Works, iii, 316): 'in regard the world, whether we take it in the larger sense for the whole universe or in the more narrow but not less common acceptance, for the globe we men inhabit, is a subject so vast'. Boyle commonly used both terms as synonymous.

${ }^{99}$ Stensen's Prodromus introduced what may be defined as a work of scientific geology, but its influence was not relevant in the seventeenth century. In later times, Locke showed a particular interest in the works by Thomas Burnet concerning the origin of the earth: his library contained Burnet's The Sacred Theory of the Earth, containing an account of the original of the earth (London, 1684; LJL, no. 534), his Archaeologia philosophica, sive doctrina antiqua de rerum originibus (London, 1692; LJL, no. 533) and his Reflexions upon the Theory of the Earth (London, 1699; LJL, no. 535), as well as other works relating to the intense debate which Burnet's writings occasioned. 
'Fossilia', as well as the deletion of 'Geographia physica' and the absence of 'Meteora' and 'Mare' (which in Scheme 1 were linked respectively to 'Terrestria', 'Aer' and 'Aqua') suggests that Locke could have been thinking of the four elements in a different way with respect to his previous scheme, perhaps as those 'unheeded agents' to which Boyle adverted in Cosmical Qualities, including stars, the ether surrounding them, the atmosphere and the earth.

Several deletions appeared under 'Animalia', where Locke had added 'Anima brutorum', 'Serpentia', 'aquatica' (which substituted the deleted 'Natantia') and 'anphybia'. 'Volucres' substituted 'volatilia' of Scheme 1. 'Serpentia' was written above 'Reptilia', which had been deleted; the species mentioned became therefore six, respectively 'Gressilia', 'Serpentia', 'insecta', 'volucres', 'aquatica' and 'anphybia'. Their order was different than that of Scheme 1, for terrestrial animals preceded the other species. In his Onomasticon Zoicon, published in 1668, the natural philosopher Walter Charleton divided species into quadrupedia, serpentia, insecta, aves and pisces; the same ordering is used in Scheme 2. Locke, then, might have taken Charleton's classification as a model ${ }^{100}$ to which he added 'anphybia', which in the Essay represented the species connecting terrestrial to aquatic animals and thus constituted an indispensable link in the chain of being. ${ }^{101}$

The addition of 'anima brutorum' is also deserving of fuller comment. In 1672, the same year in which 'Sapientia' was written, Thomas Willis published his De anima brutorum, ${ }^{102}$ heavily influenced by Pierre Gassendi's Syntagma

${ }^{100}$ Locke possessed both Charleton's Onomasticon zoicon (London, 1668, LJL, no. 669b), and his Exercitationes de differentiis et nominibus animalium (Oxford, 1677; $L J L$, no. 668). Besides, he possessed some pioneering works by seventeenth-century English zoologists such as John Caius (LJL, nos. 563- 565).

${ }^{101}$ E III.vi.12, 447.

102 Thomas Willis, De anima brutorum, quae hominis vitalis ac sensitiva est, exercitationes duae (Oxford, 1672). 
philosophicum. In contrast with Descartes, who denied animals had souls, and at the same time in contrast with Daniel Sennert, who claimed that the souls of humans and beasts are alike, Gassendi affirmed that animals must have their own peculiar souls, since they show evidence of memory, reason, and similar traits. He called this the 'soul of brutes', and spoke of its being present in man as an 'inferior' soul.

Following out Gassendi's line of thought, Willis developed his own conception of the soul grounded on Cartesian dualism, which attributed both a corporeal soul and a rational soul to man. The corporeal soul, which was inferior and possessed in common with other animals, corresponded to the Cartesian res extensa, whereas the rational soul corresponded to the res cogitans. Locke's interest in this topic, which had considerable theological implications, ${ }^{103}$ was signalled by some remarks concerning the distinction between the idea of the brute and the idea of man in the Drafts. ${ }^{104}$ If he did not dwell on animal psychology there, in the Essay he would attribute perception, memory and a limited ability to compound simple ideas into complex ones to animals, though not the capacity for abstraction. ${ }^{105}$ Several medical notes which Locke wrote at various points of his life showed a continuing interest in brute-human combinations, ${ }^{106}$ which might equally be linked to his concern with the position of man in the scale of beings. As we shall go on to see, his interest in the debate concerning the brute soul is also visible in Scheme 5. But that is

${ }^{103}$ Locke refused to attribute immortality to brute souls: see Locke, Mr. Locke's Reply, in Works, iii, 466.

${ }^{104}$ See Locke, Draft A, $\$ 41,69$; Draft $B, \S 78,185$. In later times, Locke acquired Antoine Dilly's De l'ame des bêtes (Lyon, 1676; LJL, no. 82), which represented a direct development of the Cartesian automaton theory.

105 See E II.vi.12, 447: 'There are some Brutes, that seem to have as much Knowledge and Reason, as some that are called Man'. Compare II.x.10; II.xi.5; II.xi.7; II. xi.10.

${ }^{106}$ See Dewhurst, John Locke, 78-79, 128, 163, 241, 260. See also E III.xi.20, 519 on 'monstrous Births'. 
to anticipate. Let us continue for the present to outline the more striking features of Scheme 2 .

Some new items were added under the subheading 'Anima', respectively 'Facultates', 'perceptio Imaginatio' and 'Memoria'; to these, 'Intellectus' and 'Voluntas', which were already in Scheme 1, followed. The various topics and their order recalled the various steps of that 'history of the rise \& originall of human knowledge' which Locke described in the Drafts, ${ }^{107}$ that is to say perception, the production of 'Ideas or Images of things' affecting our senses, ${ }^{108}$ their retention in the memory (the faculty reviving those images produced by objects in our mind), and their being conveyed into understanding. ${ }^{109}$ The will was the faculty on which, as Locke declared in Draft A, 'Assent, Suspense, or dissent' with respect to any proposition depended. ${ }^{110}$

'Passiones' did not figure in Scheme 2; the only mention of passions in 'Sapientia 72' was under the head Prudentia ('Passionum suarum regimen'), where they had already appeared in the previous classification. In Scheme 1, a gloss after 'Passiones' introduced an explicit reference to Theologia, which drew out what was implied in the mention of 'Creatio' under 'Materia'; both the gloss and 'Creatio' were absent from Scheme 2 , as they would be from Scheme 4 (1681). The dependence of Physica on Theologia became therefore less evident; the several topics added under the latter in 'Sapientia 72', but also the important modifications introduced in physica generalis, suggest that Locke might have been more interested, for the moment, in inquiring into the two disciplines separately. The last classification shows a radical shift in perspective in this regard.

No significant change occurred under the last subheading, 'Sensus', in Scheme 2: Locke had only deleted the adjective

\footnotetext{
${ }^{107}$ See Locke, Draft $B \S 31,140$.

${ }^{108}$ Locke, Draft $B, \S 31,128$; see also Draft $A, \S 1,1$.

${ }^{109}$ Locke, Draft B, §§ 23-24, 134-35.

${ }^{110}$ Locke, Draft A, $\S 42,73$.
} 
'mechanicae', which in Scheme 1 referred to those arts concerning tactile qualities. With this deletion, he might have intended to include medical arts (surgery, for instance), where hot and cold represented two fundamental principles: also in Scheme 4 , the adjective 'mechanicae' is absent.

Scheme 4 contains a few, though particularly interesting, novelties with respect to Scheme 2; but before examining them, it is opportune to consider the various adversaria which Locke wrote in 1677, which, though they do not represent, properly speaking, classifications, clearly illustrate the importance he assigned to the Baconian method of natural histories and to mechanical arts.

\subsection{Physica and natural histories in Locke's adversaria (1677)}

The composition of adversaria, i.e. notebooks collecting excerpta and loci communes extrapolated from discourses and orations, was an ancient practice originating in classic topics and rhetoric; it was widely employed also in the subsequent centuries. This practice underwent a rapid evolution in the sixteenth and especially in the seventeenth century, when the notebook ceased to be conceived of as a deposit for rhetorical tools and became an instrument based on conventional rules of archiving, independent from criteria relating to content. ${ }^{111}$ The method of commonplacing Locke elaborated during his time in France (1675-79), later published in Jean Le Clerc's Bibliothèque Universelle, ${ }^{112}$ was evidence of his great interest in this practice, which found expression in the many adversaria he wrote in 1677.

${ }^{111}$ Cf. J. M. Chatelaine, 'Les recueils d'adversaria aux xvie et xviie siècles: des pratiques de la lecture savante au style de l'érudition', in Le livre et l'historien. Etudes offertes en l'honneur du Professeur Henry-Jean Martin, ed. F. Barbier (Geneva, 1997). Locke's interest in cataloguing is also attested by the pigeon-hole cabinet he devised for the storage of rolled papers in 1680: see Locke to Toinard, Dec. 13, 1680, in Corr., ii, $315-22$.

112 John Locke, 'A New Method of a Common-Place-Book, Translated Out of the French from the Second Volume of the Bibliothèque Universelle', in Works, ii, 441-59. 
Locke's adversaria contained guidelines for the writing of commonplace books. The first (MS Locke f. 15, pp. 119-120, henceforth A) consisted of an undated outline entitled 'Adversaria' in Locke's pocket memorandum book for June 1677-June 1678. The outline had been crossed out with diagonal lines, indicating it had been copied elsewhere. ${ }^{113} \mathrm{~A}$ second outline entitled 'Adversaria 19 Aug 77' (MS Locke c. 28, f. 50, henceforth B), was almost identical to the first, which might have been copied here with very few additions. A third outline, which I will call here Scheme 3 (MS Locke f. 2, pp. 247-52, dated 4 Sept. 1677), was written in English, not in Latin, and not in the tabular form of the other adversaria. A fourth scheme (MS Locke f. 15, pp. 122-23, henceforth C) seemed to represent a reworking of B. Scheme 3 was less fully realised than $\mathrm{C}$, and so might have been written before it. A fifth outline, entitled 'Adversaria 12 Nov. 77' (MS Locke c. 28, f. 51, henceforth D), represented a reworking of $\mathrm{C}$, as would seem to be confirmed by a few additions and strong similarities. I will start by considering Scheme 3, which exhibits several noteworthy differences from the other adversaria.

Scheme 3 began with a declaration of intent. Locke's purpose was to find a method for identifying 'the principall parts or heads of things to be taken notice of' in 'reading books and making Adversaria'. To this purpose, he listed four headings, respectively 'Adversaria philosophica', 'Adversaria Historica', 'Adversaria Immitanda' and 'Adversaria Acquirenda'. Under each heading, some lines illustrating the object and the faculty involved were added: 'Adversaria philosophica' encompassed those topics concerning the 'knowledg of things' and requiring the use of judgment, whereas 'Adversaria Historica' incorporated those topics necessitating the use of memory (opinions and traditions concerning religion; religious and civil institutions). The practices and arts mentioned under 'Adversaria Immitanda', and the

113 There is another, incomplete outline entitled adversaria on p. 110 of MS Locke f. 15 , crossed out as that on pp. 119-120. It does not contain any topics pertaining to physics. 
'naturall products' and 'merces' cited under 'Adversaria Acquirenda', referred to the sphere of action. In A, B, C and D, the headings were three, respectively Conoscendorum, with its subheading 'Philosophica'; Reminiscendorum, to which both 'Historica civilia' and 'Historica Physica' were linked; and Agendorum, with its subheadings 'Immitanda' and 'Acquirenda'. ${ }^{114}$ Understanding, memory and will were therefore the three faculties to which Locke referred, the same triumvirate discussed by Descartes in his Metaphysical Meditations. Locke's reading of the latter, and several other Cartesian works, is attested by the journal he kept during his travels in France. ${ }^{115}$

Scheme 3 terminated with the introduction of another head, 'Historica Physica': as shown by the other adversaria, the latter was to be intended as a subheading of 'Adversaria Historica'. The object of 'Hystorica Physica' in Scheme 3 was said to be the 'history of naturall causes and effects'. This topic required the reader of books to take note of

those severall propertys of bodys \& the severall effects that severall bodys or their qualitys have one upon an other, \& principally to remark those that may contribute either to the improvem[en]t of arts or give light into the nature of things w[hi]ch is that w[hi]ch I cald above philosophica w[hi]ch: I conceive to consist in having a true cleare $\&$ destinct Idea of the nature of any thing w[hi]ch in naturall things or reall beings because we are ignorant of their essence takes in their causes propertys \& effects or as much of them as we can know, $\&$ in Morall beings their essence $\&$ consequence.

The topics to which attention should be devoted when reading books on physics (i.e. the properties and effects of things) should therefore be catalogued in two different sections for Locke, one

\footnotetext{
${ }^{114}$ A more detailed description is in Di Biase, 'Theologia, Ethics and Natural Law', $200-4$.

${ }^{115}$ On Locke's early reading of Descartes, see G. A. J. Rogers, 'Descartes and the Mind of Locke: the Cartesian Impact on Locke's Philosophical Development', in Descartes: il metodo e i saggi, ed. G. Belgioioso, G. Cimino, P. Costabel, and G. Papuli (Rome 1990), 689-97.
} 
oriented towards practice and the other towards speculation; the writing of natural histories was functional to both these orientations.

This was Bacon's teaching: natural histories were a fundamental tool, in his view, for 'laying the foundations of a true and active philosophy', ${ }^{116}$ and could be of great use, both as a means to obtain primary knowledge of particular things and as a way to collect 'the basic stuff and raw material of true induction'. ${ }^{117}$ The influence of Bacon's method of natural history on Locke's thought was lasting, ${ }^{118}$ perhaps mediated via Boyle, who had fully endorsed the Baconian programme. ${ }^{119}$ Locke's barometric readings were intended as a contribution to the writing of a history of the air, while his early medical essays 'Anatomia' and 'De arte medica' (products of his relationship with Sydenham), referred to a history of diseases. He always conceived the work of natural philosophers as a collective enterprise, aimed at accumulating data throughout time; in the Essay, the writing of histories of natural phenomena was recommended as a relevant instrument for the advancement of knowledge.

In Bacon's view, the object of natural histories was threefold. They should encompass, first, natural objects or species, second, aberrations of natural objects, and, third, the manipulation of

${ }^{116}$ Francis Bacon, Parasceve ad historiam naturalem, et experimentalem, in The Oxford Francis Bacon (15 vols., Oxford, 1985-), xi, 453. See also, in the same volume, Great Instauration, 37-38, and Novum Organum, 215.

${ }^{117}$ Francis Bacon, Parasceve, 455. Compare Descriptio globi intellectualis, in The Oxford Bacon, vi, 104-7.

${ }^{118}$ After Boyle, Bacon is the most frequently found natural philosopher in Locke's library (see $L J L$, nos. 162-78a).

${ }^{119}$ By the middle of the 1660 s, Locke had read all the works Boyle had published on natural philosophy, one of which, Certain Phisiological Essays (London, 1669), explicitly promoted the Baconian programme. Regarding Locke, Boyle and Bacon's method of natural history, see Anstey, John Locke, 51-59. 
nature by 'art and human agency'. ${ }^{120}$ Natural objects should be distributed in natural histories into five categories: celestial objects, regions of the air, earth and sea, elements (i.e. vast bodies such as mountains) and species (metals, plants and animals). In Scheme 3, Locke referred to a division of natural objects into species (a 'Historia Physica, referenda secundum species'), yet he did not mention any of them, probably considering his schemes of physics as being more suitable to this scope. Also in $\mathrm{A}, \mathrm{B}$ and $\mathrm{C}$ there was no mention of any particular species of natural objects; only in $\mathrm{D}$ did he introduce a list of species, but it was probably a later addition, as I shall try to demonstrate at the end of this section.

A 'history of naturall causes and effects', Locke noted, should mainly focus on those properties, qualities and reciprocal effects of bodies which could contribute either to the improvement of arts, or to the knowledge of things. The latter was the province of 'Philosophica' (the first heading), which encompassed both 'reall beings' (natural things) ${ }^{121}$ and 'moral beings' (moral ideas). ${ }^{122}$ The purpose of 'Philosophica', Locke continued, was the acquisition of true, clear and distinct ideas of things: truth was the first requirement imposed on ideas, before Cartesian clarity or distinctness. ${ }^{123}$ Only the essences of moral

${ }^{120}$ Bacon, Parasceve, 455; Descriptio, 98-105. The history of the arts (both mechanical and liberal) was the most useful for Bacon, because of its ability to remove 'the veil from natural things': see Parasceve, 463; Descriptio, 108-9.

${ }^{121}$ As for the meaning of this expression, see Locke's journal entry for 20 January 1677, where he opposed an 'imaginary space' to space as 'any reall being' (An Early Draft, 102).

122 The expression 'moral beings', by which Locke meant notions such as moral goodness or badness, is also to be found in Draft $B, \S 161,270$. See also E II.xxviii.14, 358.

${ }^{123}$ Unlike Descartes, Locke did not consider clarity and distinctness as twin criteria of truth: both, for him, were properties of individual ideas. Truth was a property of propositions (which consist in 'the joining or separating of signs' either in the mind or verbally: see $E$, IV.v.2, 574). The clarity and distinctness of individual ideas was a precondition for joining or separating them in propositions properly, but truth was a criterion to be applied only to the latter. Nonetheless, Locke spoke frequently of true 
ideas could be known, those of natural things being out of the reach of human understanding: this was a basic thesis in Locke's empiricism, which he argued in several of his writings. ${ }^{12}$

The object of 'Historica Physica' was more briefly characterized in the other adversaria. In A it consisted of those 'properties, effects and qualities of bodies which maximally concern use or knowledge [and] which have to be divided into groups (in capita) according to their Species'. ${ }^{125}$ The same definition reappeared in $\mathrm{B}$, in $\mathrm{C}$ (though slightly abbreviated), and in D. In A and B another topic appeared under 'Historica Physica', 'Bonitas' (that is, goodness). Its inclusion in this place became more intelligible in $\mathrm{C}$, where the term was accompanied by a gloss, 'signs (Indicia) or things known about the goodness of anything which is commonly used'. In D, the gloss was modified: 'things known and signs (signa) concerning anything which is good and perfect in its genre'. Paying attention to the supposed or known goodness or perfection of any natural object was therefore the main criterion to be observed when collecting topics under 'Historica Physica': the central purpose of composing natural histories, to determine which things could be good and useful to human life, was highlighted. This was one of Locke's

and false ideas (as also Scheme 3 testifies). In E IV.xxxii.4, 385 he explained that 'When-ever the Mind refers any of its Ideas to any thing extraneous to them, they are then capable to be called true or false. Because the Mind in such a reference, makes a tacit Supposition of their Conformity to that Thing: which Supposition, as it happens to be true or false; so the Ideas themselves come to be denominated'.

${ }^{124}$ See Locke, 'De arte medica' (1669), in Dewhurst ed., Dr. Thomas Sydenham (1624-1689). His Life and Original Writings (Berkeley, CA, 1966), 82; Draft A, 2 , 7:'we have as cleare a notion of the essence of a spirit as any one hath of the essence of body, the one being supposd to be without knowing what it is the substratum to those simple Ideas that we receive from without and the other supposd (with a like ignorance of what it is) to be the substratum to those actions we experiment in our selves within'. See also 'Knowledg its extent \& measure', Feb. 8 1677, in An Early Draft, 85. The essence of moral notions is knowable for Locke because they are 'Creatures of the Understanding': see E III.v.12, 435.

${ }^{125}$ My translation. The original in Latin is in the appendix, where the various schemes and adversaria are reproduced. 
firmest convictions: knowledge should always be increased to the end of improving the 'conveniences of this life' (a scope with respect to which human faculties were perfectly adequate). It was not an end in itself. ${ }^{126}$

As has already been said, no species of natural objects was cited under 'Historica physica' in any of the adversaria; only in $\mathrm{D}$ did a list at the bottom of the last page introduce anything of this kind. The list contained nine numbered topics preceded by an unnumbered one:

'Historica physica sc.: of incorporeal things- Spiritum; $1^{\circ}$ all those things which occur beyond our atmosphere or-Oupavık $\alpha ; 2^{\circ}$ Those things which occur in our atmosphere-Meteorica; $3^{\circ}$ [Those things which occur] In the seas, rivers and lakes-Hydrographica; $4^{\circ}$ On Earth-Geographica; $5^{\circ}$ In the kingdom of sensitivity-Animalium; $6^{\circ}$ In the intellectual kingdomHominum; $7^{\circ}$ In the vegetable kingdom-Vegetabilium; $8^{\circ}$ Subterranean things-Fossilium; $9^{\circ}$ anything in any of them going beyond the usual course of nature which is said to be a prodigy or a miracle-Mira, ${ }^{127}$

The list might have been added later, as is suggested by the smaller characters of the writing, by its location at the bottom of the page and, above all, by its content: various topics in it show relevant similarities with the contents of Scheme 5. The mention of 'Spiritum' and 'Mira' is symptomatic of the adoption of a different perspective regarding the object of 'Historica Physica', the one Locke would endorse in Scheme 5 with reference to the object of Physica. But this is only an anticipation.

The importance assigned to the 'improvement of arts' in the definition of the object of 'Historica Physica' was restated in Scheme 3 under the heading 'Adversaria Immitanda'. The object

${ }^{126}$ E I.i.5, 45; II.xxiii.12, 302.

${ }^{127}$ I do not translate 'Spiritum', 'Meteora', etc. in order to render easier comparison with the subheadings in the various schemes of Physica. As for the Greek term

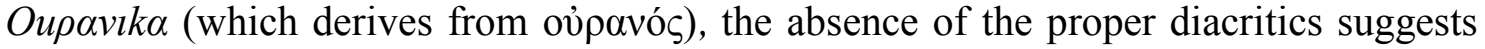
that Locke was interested primarily in the utility of general schemes for organising his own thinking rather than perfect rectitude. 
of the latter was said to encompass 'what soever wise practices are to be found either for governing of policies or a mans private self or any beneficall arts'. These practices were further distributed among three disciplines, respectively 'Politica sive Sapientia civilis', 'Prudentia sive Sapientia privata' and 'Physica sive artes'. Under the latter, in Scheme 3 Locke listed 'drinking (Potum); food (Cibum); Medicine; motion or Mechanics; Sense objects'. In A, B and C, the objects of 'Physica' were 'those arts which can be rendered apt to our use'; in D, 'industry in art practice (artis solertiam) or those things which can be accommodated to our use and possessions'. Under 'Physica', in A Locke listed 'Food; Drinking; Medicine; Veterinary science; Mechanics; Chemistry; Pharmaceutics'; the last two were probably added later, for they were absent from B but reappeared in C. Some other topics were added in a separate column, i. $e$. motion (which was linked to Mechanics, the scientia motus), sense objects (sensuum objecta), things helping senses (sensus adiuvandos), things which have to be preserved or improved on (res conservandas vel meliorandas), the species of all these things (haec omnia Species). These topics were all to be intended as objects of different arts; the list reappeared slightly modified in B, with 'Clothes' (Vestitum) being added after 'Drinking'. ${ }^{128}$ The other topics, again slightly modified, were present: 'motion; sense objects; senses to be sharpened (sensus acuendos); things to be improved on or preserved; all these things according to their Species'. In C, oeconomiam was added after 'Clothes'. Locke had previously written, and then deleted, supellectilem (furniture) in its place. Pharmaceutics and chemistry reappeared before veterinary science. The list ended with a reference to the other arts (aliaque artes). No relevant change appeared in D, apart from

128 'Veterinaria' seems to have been added later both in A and B, given the lack of space between the topics preceding and following it; also 'Vestitum' in B seems to be a later addition. Both the topics reappear in $\mathrm{C}$; Locke might have copied them in the previous adversaria when composing the latter. 
the substitution of oeconomiam (which was also mentioned under 'Prudentia' in C and D) with supellectilem. ${ }^{129}$

The growing number of mechanical arts mentioned in the adversaria is evidence of the great value which Locke attributed to the practice of them (the promotion of solertia in D), even of the lowest ones such as vestiaria. By contrast, major arts such as architecture, painting and sculpture, were not cited (the first would be introduced in Scheme 4, whereas the second was mentioned in Scheme 1 and 2). Like Bacon and Ames, but also like Samuel Hartlib, whose ideas on a universal reformation were surely of great interest to both Boyle and his entourage, ${ }^{130}$ Locke wished to highlight the great moral and educational value of mechanical arts. Their relevance would be confirmed by the Essay, where the practice of 'useful arts' was characterized as a fundamental ingredient for the flourishing of human societies, ${ }^{131}$ and emphasised yet more strongly in Some Thoughts concerning Education, where Locke would insist on their educative value. ${ }^{132}$

${ }^{129}$ On a loose sheet in 'Adversaria 1661' located between pp. 24 and 25, an incomplete adversaria containing only 'Historica Physica' and 'Agendorum Immitanda-Acquirenda' is to be found. The definitions of 'Historica Physica' and 'Acquirenda' are more similar to those in B than those in A or in the other adversaria, though the topics listed under 'Physica sive artes' are less numerous than those in B or A. One of them, 'adjutoria' recalls the 'sensus adiuvandos' in A more than the 'sensus acuendos' in B, C and D. The incomplete adversaria might therefore have been written between A and B. A description and transcription of the manuscript is accessible via The Digital Locke Project, directed by Paul Schuurman (Amsterdam, 2006), further details of which are available from http://www.libraries.psu.edu/tas/locke/ index.html\#jca.

${ }^{130}$ Regarding the relationship between Boyle, Hartlib and the 'Invisible College', see Michael Hunter, Boyle's Studies: Aspects of the Life and Thought of Robert Boyle (1627-91) (London, 2015), esp. 44-48; regarding Locke and Hartlib, see (with reservations) N. Wood, John Locke and Agrarian Capitalism (Berkeley, 1984), esp. 2226.

${ }^{131}$ E IV.xii.11, 646; see also III.x.9, 495, where he deplored the bad reputation of the mechanical arts.

${ }^{132}$ Cf. Some Thoughts concerning Education, ed. J. W. and J. S. Yolton (Oxford, 2003) §202, 256, where Locke listed 'Painting, Turning, Gardening, Tempering and Working in Iron, and all other useful Arts'; in \$206, 258, he added 'Delving, Planting, Inoculating', and in $\$ 209,260$ 'Perfuming, Varnishing, Graving and several sorts of 
Besides, the list of arts in the adversaria was indicative of Locke's personal interests: this was clearly the case with medicine, chemistry and pharmaceutics (whose presence also highlighted the increasing relevance it had assumed in seventeenth-century English medicine). ${ }^{133}$ Veterinary science, too, had attracted Locke's interest during his time in France, as some notes in his journals attest. ${ }^{134}$ Sensus adiuvandos/acuendos might refer to optical devices (optica would be introduced in Scheme $4),{ }^{135}$ as well as to acoustic devices. ${ }^{136}$ Res conservandas vel meliorandas was an expression used in the Codex civilis with

working in Iron, Brass, and Silver...to cut, pollish and set precious Stones [and] grinding and polishing Optical Glasses'. The art of keeping accounts was recommended in $\$ 208,260$; manual arts were lauded in $§ 207,259$.

${ }^{133}$ A great part of Locke's medical activity consisted in the preparation of remedies, as his notes and correspondence suggest; he possessed several treatises on pharmacology and recipe books, such as those by Valerius Cordus, Leonardo Fioravanti and Luigi Anguillara ( $L J L$, nos. 846, 1127 and 94). He also possessed, among others, a work by the Helmontian Johannes Michaelis, whom he described in a note in his diary of 6 November 1685 as 'the incomparable chemist of Leipsig' ( $L J L$, no.1987b). The complete catalogue of books on pharmacology in Locke's library is in $L J L$, Appendix v, 303; for chemistry, see 294.

${ }^{134}$ John Lough, Locke's Travels in France 1675-79 (Cambridge, 1953), 247. See also K. Dewhurst, 'Some 17th-century veterinary notes from the journals of John Locke (1632-1704)', Veterinary Record 74 (1962): 996-99. Much of the information concerning the care of animals fell under the heading 'husbandry' in the seventeenth century, a subject whose study Locke recommended in Some Thoughts; also almanacs were important sources of information on veterinary science, and Locke was particularly interested in them (see $L J L$, nos. $78 \mathrm{a}, \mathrm{b}$, c etc.; see also Locke to Toinard, 10 June 1680, Corr., ii, 194).

${ }^{135}$ Locke had read Descartes' Dioptrique in the early sixties: see G. A. J. Rogers, Locke's Philosophy: Content and Context (Oxford, 1994), 37-38. Only two texts on optics, both by personal acquaintances, are to be found in Locke's library, the Dioptrica nova of William Molyneux and Newton's Optica (LJL nos. 2011 and 2082).

${ }^{136}$ Bacon had shown particular interest in 'ear-spectacles' (ear-trumpets) in his Sylva Sylvarum. Locke surely knew Samuel Morland, the author of Tuba StentoroPhonica: an Instrument of Excellent Use, as well as at Sea, as at Land (London, 1672). Locke possessed other works by Morland, in particular one on cryptography: LJL, no. 2054a). In 1681, Nicolas Toinard reported to him on the 'Acoustique' devised by Jean Hautefeuille (Corr., ii, 344). 
reference to the administration of the patrimony, and therefore to be linked to the artes oeconomicae.

A mention of Physica was also to be found under the first heading, 'Philosophica', though not in all the adversaria. In Scheme 3, the object of 'Philosophica' was said to be 'the knowledge of things their essence and nature, properties causes and consequences of each species'; since only the essence of moral ideas could be known for Locke (as he declared under 'Historica Physica'), the 'things' to which 'Philosophica' referred embraced both real objects and moral ideas. In A, the object of 'Cognoscendorum: Philosophica' was said to be 'whatever may lead to the knowledge of beings (entium) and their causes, properties, effects and consequences so as to have true, clear and distinct ideas of them. Anything occurring of this sort which has to be divided into groups according to the various species of things (rerum)'. No mention was made of essences; however, two topics added in $\mathrm{B}$ and in $\mathrm{C}$ to the definition of 'Philosophica', respectively 'Ethica' and 'Physica', clarified which were the entia to which Locke was referring. Ethics came before physics, as in Scheme 1 and 2: the priority attributed to the first conformed to the hierarchy of duties established by Locke in 'Study', to which his classifications conformed.

In $\mathrm{D}$, some relevant changes occurred regarding the object of 'Philosophica', which was characterized in these terms:

whatever may lead to the philosophical knowledge of beings (entium), so as to have true, clear and distinct ideas of their essences, causes effects. 1 those things which pertain to being in general, or Metaphysica, 2 [those things which pertain] to the species of being (specierum entis), or Physica, 3 those things which depend on human will, or Ethica.

Physics figured as one of the disciplines pertaining to reason, that is, to 'philosophical knowledge'. Its objects were the various

${ }^{137}$ Several references to the way of administrating one's patrimony are to be found in Locke's economic writings, as well as in the second of Two Treatises of Government and Some Thoughts concerning Education. 
'species of being', an expression which was not in any of the previous adversaria, where Locke had written 'species of things' (Scheme 3; 'rerum species' in A, B, C). The last lines in the passage cited just now (those concerning metaphysics, physics and ethics) might have been added later, given the smaller characters of the writing and the deletion of two lines, which they substituted. Locke had initially written: 'everything of this sort which is to be divided into groups according to the various species of things', the same sentence which was in the other adversaria, but then he had deleted it and added the new lines concerning metaphysics, physics and ethics. The definition of Physica seemed to have been thought of in strict correspondence with that of metaphysics: the latter represented the science of being in general (the Scholastic ens commune), the former the science investigating the various species of ens.

Locke's source might have been Francisco Suárez, whose (direct or mediated) influence ${ }^{138}$ was discernable in the classification of 1681 in the priority attributed to Metaphysica with respect to Theologia. In his Metaphysicarum disputationum, Suárez affirmed that the purpose of the various sciences was 'contemplari varias species entis secundum proprias \& specificas rationes scibilis'. This was what differentiated them from metaphysics, the only science which considered 'omnes species entis sub communi ratione entis'. ${ }^{139}$ Locke might have returned to adversaria $\mathrm{D}$ in 1681 when composing his third classification which, by its contents and organisation, hints that his interest in

${ }^{138}$ Burgersdijck's Institutionum Metaphysicae, one of the main textbooks on metaphysics studied at Oxford in Locke's time, showed Suárez's influence; the introduction of metaphysics in 'Sapientia' and in the classification of 1681, as well as the precedence attributed to the discipline, might be traced back to his influence, or directly to that of Suárez. As I have argued in 'Theologia, Ethics and Natural Law', 191-93, the priority of metaphysics in 'Sapientia' is detectable from the numeration (Theologia is numbered 2, Metaphysica 1), not from the effective ordering of the disciplines (Theologia precedes Metaphysica). It is probable that Locke added the numbers in 1681 , when composing his new classification.

${ }^{139}$ See Francisco Suárez, Metaphysicarum disputationum (2 vols., Mainz, 1614), i, sec. II, chs. xxi-xxii, 13. 
metaphysics had grown significantly. The new lines written under 'Philosophica' in place of the deleted ones, but also the addition of 'Metaphysica' after 'Ethica' and 'Physica', which were already included under 'Philosophica' in both $\mathrm{B}$ and $\mathrm{C}$, might have represented the outcome of a subsequent intervention on $\mathrm{D}$. This seems to be confirmed both by the presence of a curly bracket enclosing 'Ethica' and 'Physica', but leaving 'Metaphysica' out, and by the contrast between the numbers added to the disciplines and their order ('Metaphysica' was numbered ' 1 ' but followed the other two). These later adjustments focussed on the first part of D, the one containing 'Philosophica'; the interest in Suárez's metaphysics clarified the peculiar definition of 'Physica'. However, Locke, it seems, returned again to D when composing his last, troubled classification of 1687. Some similarities between the topics listed at the bottom of the last page of $D$, referring to 'Historica Physica', and those in that classification appear to support this hypothesis. Locke's modifying D twice when writing new classifications suggested he might have conceived of both the latter and the adversaria as parts of a single, complex attempt to map the mundus intellegibilis.

The contribution which the various adversaria offer to the understanding of Locke's conception of Physica is easy to overlook. Yet they highlight the importance he assigned to the method of natural history, as well as the priority he attributed to the improvement of useful arts with respect to speculation. The structure of the adversaria did not allow him to represent the hierarchical order of the various sciences (which was exactly what Locke was attempting to introduce in D when numbering ethics, physics and metaphysics under 'Philosophica'). This might have been one reason for his preferring classifications. At the least, the classification he worked out in 1681 provides some possible evidence in support of this speculation.

\subsection{Scheme 4. Physica in Bodl. MS Locke c. 28, ff. 157-58}

Locke wrote two classifications in 1681, 'Adversaria 1661', ff. 290-291, and MS Locke c. 28, ff. 157-58. They are almost 
identical, the second being a fair copy of the first. As regards the outline of Physica (Scheme 4), in both Locke added a new element, 'Vaccuum', under 'Mundus sive Universum' and 'Materia Corpus', the two topics which pertained to physica generalis. The addition was not a homage paid to Aristole's Physica, where void was one of the arguments treated. The existence of void was a controversial topic, to which Locke had already referred in Draft A without taking a clear stand on the issue. ${ }^{140} \mathrm{He}$ had simply contrasted the Cartesian plenist account of matter with the vacuist account, in order to show how reasoning based on innate principles was inadequate in determining which (if either) was right. In a journal note written in 1677, he discussed the notion of distance in Cartesian terms, explaining that space was a 'bare relation' between bodies, but in the closing paragraph he proposed an alternative hypothesis, probably inspired by the reading of More's Antidote against Atheism: 'If it be impossible to suppose pure noe thing or to extend our thoughts where there is or we can suppose noe being this space void of body must be something belonging to the being of the deity'. ${ }^{141}$ The paragraph introduced the anti-Cartesian idea of a real but penetrable, and hence incorporeal, space, intended as a divine extension. This idea would be further developed in the Essay, where Locke would introduce the notion of pure space as an idea of the mind completely distinct from that of solidity that

${ }^{140}$ Draft A, §27, 46.

${ }^{141}$ See, An Early Draft, 96 (for 16 September 1677). In the Appendix of An Antidote to Atheism (1655), ch. 7, §6, 338, More had written 'if after the removal of corporeal matter out of the world, there will be still place and distance in which this very matter, while it was there, was also conceived to lye, and this distant space cannot but be something, and yet not corporeal, because neither impenetrable nor tangible, it must of necessity be a substance incorporeal necessarily and eternally existing of itself; which the clearer Idea of a Being absolutely perfect will more fully and punctually inform us to be the self-subsisting God'. Locke owned two copies of the discussion contained in the appendix, which was printed both in the 1655 edition of the Antidote and in the 1662 Collection of Several Philosophical Writings (LJL, nos. 2047 and 2046). See Jasper Reid, The Metaphysics of Henry More (Dordrecht, 2012), 137-38. 
accompanies the materiality of bodies. ${ }^{142}$ The reading of More's work might have played an important role in leading Locke away from a Cartesian, or Hobbesian, identification between extension and body. Certainly it opened up the possibility of rethinking the notion of body and therefore the object or objects of physica generalis, as Scheme 5 and the 'Division of the Sciences' at the end of the Essay would go on to illustrate.

The addition of 'Vaccum' in Scheme 4 was symptomatic of Locke's mature conviction of the existence of a void. The latter was also one of the topics of his intense correspondence with the French erudite Nicolas Toinard in 1680, with whom he had become acquainted during his stay in France.

Toinard's interest in natural philosophy was particularly marked. In that year, 1680, he was conducting several experiments, one of which concerned the possibility of cooking food in a void, another the possibility of creating a void in a receptacle capable of containing a man. ${ }^{143}$ Toinard faithfully reported on these experiments to Locke. The addition of 'Vacuum' in Scheme 4, as well as that of other topics, might be linked to their correspondence; this also seems to be the case for 'Chronologia', added after 'Astronomia'. Several letters which Locke addressed to and received from Toinard around this time concerned horology and the reform of the English calendar. ${ }^{144}$

${ }^{142}$ E II.iv.3, 124.

${ }^{143}$ See Toinard to Locke, Oct. 4, 1680, Corr., ii, 255-56. Toinard invited Locke and Boyle to test whether salted food lost its taste in a void (ii, 266). Locke expressed interest in both experiments (Locke to Toinard, Oct. 4, 1680, ii, 268-69).

${ }^{144}$ On July 12, 1679 (Corr., ii, 48), Toinard sent the design of a clock capable of five strokes a second, devised by Rømer, to Locke; Rømer sent a more detailed description of the clock to Locke on July 19, 1679 (ii, 50). On 16 Sept. 1680, Locke informed Toinard that he had asked Thomas Tompion, 'the best watchmaker of the town', for a device his French friend was looking for (a 'divideing plate' to cut clock wheels accurately; see ii, 251-52); on Dec. 13, 1680, Locke asked Toinard for the description of a small pendulum capable of great precision, devised by Isac Thuret (ii, 319), and in February 1681 he sent to Toinard the design of a clock of his own devising, whose dial marked six hours and their parts (ii, 373). Sporadic remarks on horology appear in the correspondence of the following years. Regarding the measurement of time, see E, II.xiv.18-24, 187-92. On Nov. 29, 1680 (Corr., ii, 309), Locke sent a book 
The addition of 'Aether' before the four elements grouped under 'Coelum' (which substituted 'Coelestia' of Scheme 1 and 2) might be related to Locke's meetings with Boyle in $1681 .{ }^{145}$ In a journal note for June 26, Locke spoke of an experiment which Boyle had shown him regarding the phenomenon of phosphorescence. Locke referred to Boyle's treatise on this phenomenon, Aerial Noctiluca, which had appeared in 1680. In this work, Boyle spoke of the 'subtle Aetherial matter, that abounds in the pores of the Air'; ${ }^{146}$ moreover, the cosmic ether was the subject of a letter Isaac Newton had addressed to Boyle in $1679,{ }^{147}$, which he may have reported to Locke.

The location of 'Aether' below 'Vaccuum' in Scheme 4 merits a word, for it clearly revealed that Locke did not conceive the former as the fundamental medium for the communication of motion by successive impact. This was the central function assigned to the ethereal fluid in the mechanical system outlined by Descartes, where it was introduced as the best explanation of all those experiments disproving the existence of a vacuum. Rather, as shown by the Essay, Locke considered ether as the possible explanation of extra-mechanical phenomena such as cohesion or magnetism; this was also the function which Boyle assigned to it, though Locke appeared to be less optimistic than Boyle regarding the explanatory power of this hypothesis. In his Sceptical Chymist, Boyle seemed to accept the existence of a materia subtilis agitating the particles of matter, and in other works of his he introduced the existence of ether as a plausible hypothesis. In his Cosmical Suspicions, for example, he stated

by the mathematician Jonas Moore to Toinard, concerning a way of reforming the English calendar. References to this topic are also in the letter Locke sent to Toinard on June 10, 1680 (ii, 191) and in the correspondence of the subsequent years.

${ }^{145}$ See Dewhurst, John Locke, 201, 203, 207, 208.

${ }^{146}$ Dewhurst, John Locke, 203; see Boyle, Aerial Noctiluca (London, 1680), 37; $L J L$, no. 438.

${ }^{147}$ CUL MS Add. 9597/2/18/62-65, dated Febr. 28, 1678/9. 
that the subtle particles composing ether could account for the absence of a complete void and the mechanical interactions between bodies, as well as for other phenomena such as cohesion, magnetism and, possibly, gravity, which were inexplicable on the basis of the purely mechanical interactions of macroscopic bodies. ${ }^{148}$ The results of Boyle's attempts to demonstrate the existence and properties of the Cartesian materia subtilis were controversial, ${ }^{149}$ yet a lack of experimental evidence was not the reason why, in the Essay, Locke declared the hypothesis of ether inadequate to account for cohesion. ${ }^{150}$ The various objections ${ }^{151}$ he moved in this regard showed he considered it as an 'ingenious' tool, which obscured or postponed the real problem, our total

${ }^{148}$ Boyle, Cosmical Suspicions, in Works, iii, 316-17. Boyle differentiated between two kinds of ethereal matter, one fit for the propagation of mechanical motions across distances, the other possessing powers adequate to account for extra-mechanical phenomena like magnetism, in which the forces at work were apparently of a unique kind and could not therefore be reduced to universal, orderly mechanical motions. The first kind of ethereal matter consisted in 'more numerous and uniform sorts of minute particles', the second in 'peculiar sorts of corpuscles that have yet no distinct name, which may discover peculiar faculties and ways of working, when they meet with bodies of such a texture as disposes them to admit, or to concur with, the efficacy of these unknown agents'. The right- and left-handed screw-shaped magnetic particles to which Descartes referred in the Principia were probably only a highly speculative hypothesis for Boyle; he mentioned the different 'bigness and figure' which Cartesians attributed to ethereal matter only en passant in his Cosmical Qualities (Works, iii, 309).

${ }^{149}$ Experiment xxxviii described in A Continuation of New Experiments PhysicoMechanical, Touching the Spring and Weight of the Air, and their Effects (Works, iii, 250-56), neither confirmed nor disproved the existence of materia subtilis, though Boyle interpreted it as possible proof of its peculiarities with respect to air.

${ }^{150}$ See $E$, II.xxiii.23, 308: 'that Hypothesis, how ingeniously soever explained, by shewing, that the parts of sensible Bodies are held together, by the preassure of other external insensible Bodies, reaches not the parts of the Aether it self; and by how much the more evident it proves, that the parts of other Bodies are held together, by the external pressure of the Aether, and can have no other conceivable cause of their cohesion and union, by so much the more it leaves us in the dark, concerning the cohesion of the parts of the Corpuscles of the Aether it self'. The word 'ingenious' is ambivalent, at once conveying respect for the pedigree of the author of the hypothesis while at the same time implying cleverness in combining ideas rather than veracity.

${ }^{151}$ See Anstey, John Locke, 106-8. 
ignorance of the internal constitution of matter. An ethereal matter holding the various parts of bodies and of the universe together was an incognita as much as the phenomena which it was intended to explain.

'Meteora', which had appeared only in Scheme 1, reappeared in Scheme 4 after 'Aer', the second element: its addition was symptomatic of Locke's increasing interest in atmospheric phenomena, clearly attested by a list of topics he penned in 1682 entitled 'The Titles of the Natural and Experimentall History of ye Air'. ${ }^{152}$ The list was reminiscent of the method Boyle adopted to structure several of his works, including his posthumous General History of the Air to which Locke, whose interest in meteorology was closely linked to Boyle's research in this field, contributed significantly.

After the fourth element, 'Aqua', several topics were added in Scheme 4, respectively 'Oceanus', 'Fluvii', 'ffontes', 'Thermae' and 'Acidulae'. None of these was in Scheme 2; in Scheme 1, Locke had mentioned only 'Mare'. 'Oceanus' recalled Locke's keen interest in transoceanic voyages and explorations, ${ }^{153}$ but also Toinard's inquiries concerning the possibility of sweetening sea water, ${ }^{154}$ and Locke's interest in what Boyle had written on this subject (particularly his 1673's Observations about the Saltness of the Sea, where he dealt with the preparation of fresh water

${ }^{152}$ Bodl. MS Locke c. 42A, pp. 16-17.

153 This interest was well attested by the correspondence with Toinard: see Toinard's letter to Locke of March 5, 1681 (Corr., ii, 387), where the former spoke of the voyage of the Admiral Sir John Narbrough to the Strait of Magellan (1669-1671); Toinard to Locke, July 16, 1681 (ii, 423), where he reported on the translation of Jean Struys' book on Siam (1676) into French. Locke sent Toinard a report written by the traveler Robert Knox on the island of Ceylon: see Locke to Toinard, Aug. 30, 1681, (ii, 437). The list of travel books in Locke's library is very substantial: see $L J L$, Appendix $\mathrm{V}, 307-8$.

154 Toinard had devised a machine capable of cooking food in a bain-marie of sea water, which he thought could be of great help to ship's crews: see Toinard to Locke, Dec. 4, 1680, Corr., ii, 295-96. In a journal entry for Dec. 5, 1678, Locke reported that, according to Toinard, 'the secret to sweeten salt water' had been discovered: see Dewhurst, John Locke, 148. Locke added the name of John Wilkins, followed by ? 
from sea water by distillation). ${ }^{155}$

As for 'Thermae' and 'Acidulae', both related to Locke's interest in medicine and chemistry. Several works in his library concerned or mentioned mineral water, ${ }^{156}$ which according to Boyle 'whether Acidula, as those of the German Spaw, our Tunbridge, \&c., or Thermae, such as those of Bath, \&c., tho' but natural medicines, are, some of them, by being outwardly administered, known, singly, and in their native simplicity, to cure several diseases'.

After 'Terra' Locke reintroduced 'Geographia', which was already in Scheme 1 but had been deleted in Scheme 2. Geography represented one of Locke's constant interests, faithfully recorded by his library as well as by his correspondence with Toinard: the mention of the French astronomer Picard and of his telescopic observations, aiming at collecting reliable longitudinal data in order to redesign the chart of France, was frequent in the letters they exchanged in the years 1679-81.

Toinard was also an important source of information for Locke on botany. ${ }^{159}$ However, there was no trace of this in Scheme 4

${ }^{155}$ In 1683, Boyle addressed a letter on this subject to the Royal Society; see R. E. W. Maddison, 'Studies in the Life of Robert Boyle, F. R. S., Part II: Salt Water Freshened', Notes and Records of the Royal Society of London 9 (1952): 196-216.

${ }^{156}$ See LJL, nos. 1651 b (Laguna), 740 (Claudini), 930 (Dean), 1585 (Jorden), 658 (Chapman), 1407a (de Heer), 1251 (Le Givre), 352 (Blondel); a work on this subject by Samuel Cotterau du Clos, whom Locke met in France in 1678, is also to be found in his library ( $L J L$, no. 789 ), as well as two works by the Helmontian William Simpson (LJL, nos. 2684 and 2685).

${ }^{157}$ Robert Boyle, The Notion of Specific Remedies Prov'd agreeable to Mechanical Philosophy (1686), in Works, iii, 592. See LJL, no. 468.

${ }^{158}$ See for instance Toinard to Locke, Aug. 16, 1679, Corr., ii, 64.

${ }^{159}$ See Dewhurst, John Locke, 150, 151, 177; Lough, Locke's Travels, 256; Toinard to Locke, May 31, 1681, Corr., ii, 401; also July 25, 1687, iii, 228; July 16, 1688, iii, 481. Occasionally, Toinard benefited from Locke's competence as a botanist: see Toinard to Locke, Aug. 28, 1680, ii, 232, where he asked for some cochlearia seeds and some potatoes cultivated in London. Locke also sent some seeds to botanists in Montpellier when he returned to England (see Locke to Toinard, Feb. 20, 1681, ii, 380). 
under 'Vegetabilia' as in the previous schemes. As for 'Animalia', the list of topics collected under this subheading included respectively 'Gressilia', 'Serpentia', 'Reptilia', 'Insecta', 'Volucres', 'Aquatica' and 'Amphybia'. The only variation with respect to Scheme 2 was the addition of 'Reptilia', which had been deleted in the latter. ${ }^{160}$ In Charleton's Onomasticon Zoicon, reptiles were not among the species considered.

Locke's correspondence with Toinard might have been a possible source of inspiration in this case too. In 1679-81, the latter reported to Locke on the discovery of new species of animals in remote lands, including the 'quirquinchos' of Chile, a new species described by the Jesuit Alonso de Ovalle, which Locke would mention in the Essay. ${ }^{161}$. The quirquincho bore some similarities to reptiles as regards its external armour, a detail which Locke might have noted. (This is only a hypothesis).

What may be more significant is the recurrence of the Biblical number seven in the classification of 1681. Seven are the species of animals listed, as well as the sciences mentioned in the classification (respectively 'Metaphysica', 'Theologia', 'Politia', 'Prudentia', 'Historia', 'Physica' and 'Semiotica', according to their numeration). Seven are also the subheadings of Theologia, as well as those listed under Physica ('Mundus sive Universum', 'Coelum', 'Vegetabilia', 'Animalia', 'Homo', 'Corpus humanus' and 'Sensus'). ${ }^{162}$ This might not be casual: a growing interest in theology (in particular, in Puritan theology) is visible in the

${ }^{160}$ On Sept. 9, 1679 (Corr., ii, 85), Toinard reported to Locke on the discovery of two new species of animals, the "Quirquinchos" of Chile described by the Jesuit Alonso de Ovalle and the "Biscachas" of Tucuman. Later, Toinard reported on the "Zambuigi", the Cape hunting dog living in Angola (Oct. 4, 1681, ibi, II, 442). On Aug. 27, 1678 (ibi, I, 606), Toinard had already spoken to Locke of "Empacaces", a kind of buffalo found in Angola described by Andrew Battel.

${ }^{161}$ E III.vi.9, 445.

${ }^{162}$ The seven subheadings are much more easily recognizable in the classification in 'Adversaria 1661', pp. 290-91 (the draft for Scheme 4), which was penned by Locke. Scheme 4 was copied by his amanuensis Sylvester Brounower. 
classification.

No significant change occurred in the list of topics under 'Anima', where the only novelty was the allocation of 'Imaginatio', which in Scheme 2 was written on the same line as 'Perceptio', below the latter, as a separate faculty. This modification recalled the content of some journal notes written by Locke in 1677-78, where he devoted special attention to the disorders of imagination: in Scheme 4 he clearly intended to emphasize the distance between perception and imagination, which had also been insisted on by Descartes in the Meditations. ${ }^{163}$ Nothing had changed under the subheading 'Corpus humanum', whereas some adjustments had been made under 'Sensus': after 'Extensio. Geometria', another topic, 'Architectura' was added with its three subdivisions, 'Militaris', 'Civilis' and 'Navalis'. Yet again Locke's correspondence with Toinard could have been a possible source of inspiration: in 1679, the latter had recommended one of his inventions to Locke, a ship with three keels, asking him to find a buyer in England. He had also reported on some interesting works on ships. ${ }^{164}$

'Pondus', which in the previous schemes was one of the objects of mechanics alongside gravity, did not appear in Scheme 4. Locke had finally resolved to adopt the new scientific terminology, according to which mechanics was the science of motion, not of weight.

A new topic, 'Lux Optica', was added under 'Sensus', before 'Colores'. In 1670-72, Newton had delivered several lectures concerning optics at Cambridge, sustaining his new, antiperipatetic theory of light - a topic which he had been

163 Locke, 'Madnesse', 5 Nov. 1677, in Dewhurst, John Locke, 89; 'Madnesse Folly', Nov. 11,1677, in, An Early Draft, 98.

${ }^{164}$ On May 24, 1679 (Corr., ii, 21), Toinard asked Locke to contact Sir William Petty, who had devised some experimental ships; Toinard's ship was an improvement of one devised by Pitt. See also the note for July 4, 1678 in Lough, Locke's Travels, 19899, where Locke reported on what Toinard had told him about a book by a "Mr. Gravier", concerning the building and equipping of ships. Locke and Toinard continued to touch on the matter in their correspondence in subsequent years. 
investigating since 1666-and introducing his mathematical theory of colours as an example of the value of mathematics in natural philosophy. ${ }^{165}$ An article reporting on Newton's experiments had appeared in Philosophical Transactions at the beginning of 1671, ${ }^{166}$ and Locke was probably aware of Newton's optical works from his numerous contacts with the members of the Royal Society. ${ }^{167}$ However, it is more probable that, in introducing light and optics in Scheme 4, Locke was thinking of the recent discoveries made by the Danish astronomer Olaus Rømer, to whom he had been introduced in Paris by Toinard.

In 1677, Rømer had been able to establish the speed of light through his telescopic observations of the satellites of Jupiter, as was faithfully reported in the Demonstration he published both in the Journal des Sçavants and in the Philosophical Transactions. ${ }^{168}$ Locke admired Rømer's optical devices, as his correspondence and journal reveal; ${ }^{169}$ he brought one with him when, in April 1679, he left France to return to England.

The intense correspondence with Toinard, who acted as an intermediary between Locke and his new French acquaintances, but also some meetings with Boyle, seems to have left a deep impression on Scheme 4: this was no longer conceived uniquely

165 See Optical papers of Isaac Newton, vol.1: The optical lectures 1670-72, ed. A. Shapiro (Cambridge, 1984).

166 'A Letter of Mr. Isaac Newton...containing his new theory about Light and Colours', Philosophical Transactions of the Royal Society of London 6 (1671): 30753087.

167 See G. A. J. Rogers, 'Locke, Newton and the Enlightenment', Vistas in Astronomy 22 (1978): 471-76.

${ }^{168}$ O. C. Rømer, 'Démonstration Touchant le Mouvement de la Lumière Trouvé par M. Römer de l'Académie Royale des Sciences', Journal des Sçavants (1676): 233-36; 'A Demonstration Concerning the Motion of the Light, Communicated from Paris, in the Journal des Sçavants, and Here Made English', Philosophical Transactions of the Royal Society of London 12 (1677): 893-94.

${ }^{169}$ In a letter to Toinard of May 1679 (Corr., ii, 11), Locke mentioned Rømer and one of his inventions, a telescope whose workings he described in a journal note for March 28, 1679 (Lough, Locke's Travels, 282). 
as a map of studies but also as a sort of diary recording Locke and his acquaintances' scientific experiences. The different treatment which Physica received in Scheme 5 revealed the influence of a different milieu, Holland, where he resided from 1683 to 1689 . It also revealed a new object of imitation and emulation on Locke's part, Alsted's Encyclopaedia.

\subsection{Scheme 5. Physica in MS Locke c. 28, fos. 155-56 and the 'Division of the Sciences' in the Essay}

The last classification which Locke wrote before the 'Division of the Sciences' in the Essay was an extremely tormented one, as the presence of several deletions indicates. It dates to $c .1687 .{ }^{170}$ The classification contained the outlines of only two disciplines,

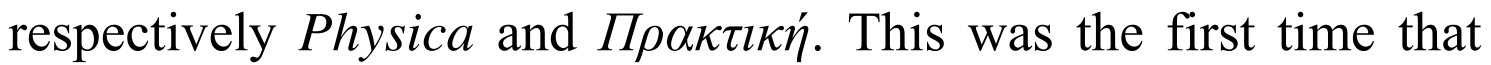
physics had occupied the first place in Locke's classifications, which is evidence of the new epistemic status he was conferring on it. Other important evidence confirmed this: the heading Physica was placed at the top of the first page (f.155r), and was followed by a list of five disciplines each marked by a number,

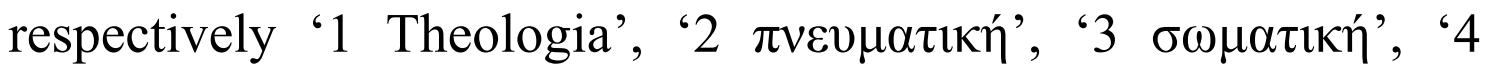
'Apı $9 \mu \varepsilon \tau \imath \kappa \eta '$ ' and '5 $\gamma \varepsilon 0 \mu \varepsilon \tau \rho i ́ \alpha$ '. Pneumatics was a term frequently used by seventeenth-century Reformed theologians to identify the science concerning spiritual entities such as angels; ${ }^{171}$ both theology and pneumatics therefore referred to incorporeal beings. Physica, then, was no longer conceived uniquely as the science of material bodies, as in the previous schemes. The corporeal and spiritual domains were both included in its subject.

${ }^{170}$ On the basis of similarities in size of sheets and layout, Schuurman argues that $\mathrm{ff}$. 155-156 were written immediately after "Of Ethick in General" (ff. 145-52) and probably also date from ca. 1686-1687. See Digital Locke project. Text descriptions, available from: http://www.libraries.psu.edu/tas/locke/ index.html\#jca. A reference to Essay, IV, xxiii, 20 appeared at the top of f.155r; the manuscript was written by Locke.

${ }^{171}$ See J. Musselius, Disputatio pneumatica de angelographia (Wittenberg, 1625); J. Scharfius, Pneumatica hoc est scientia Spirituum Naturalis (Wittenberg, 1629); J. Prideaux, Hypomnemata logica, rhetorica, physica, metaphysica, pneumatica, ethica, politica, oeconomica (Oxford, 1650). 
The scheme of $\Sigma \omega \mu \alpha \tau \imath \kappa \eta$, the third discipline in the list, was introduced below this with its eight subheadings:

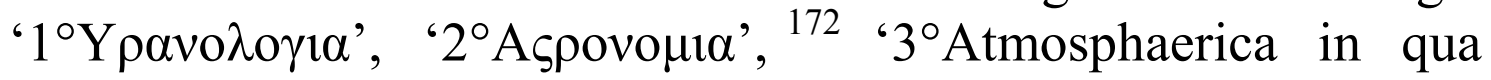
meteorologia', '4 Hydrographia', ' $5^{\circ} \mathrm{Geographia}$ ', ' $6^{\circ}$ Fossilia', ' $7^{\circ}$ Vegetabilia', and ' $8^{\circ}$ Animalia'. The subheadings were the result of several deletions. On the following page $(155 \mathrm{v})$, too, many deletions appeared. The scheme of $\Sigma \omega \mu \alpha \tau \iota k \eta$ terminated on

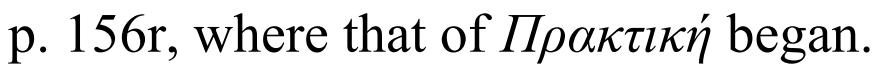

$\Sigma \omega \mu \alpha \tau \imath k \eta$ covered the field of physica specialis, as was shown by its subheadings; the content of physica generalis was therefore to be identified with that of the other disciplines listed on f. $155 \mathrm{r}$, theology, pneumatics, arithmetic and geometry. These were all theoretical sciences. Their location below the head Physica suggests that Locke was thinking of physica generalis as a speculative science encompassing all these disciplines.

There are some striking resemblances between the list of disciplines at the beginning of Scheme 5 and the list of theoretical sciences in Johann Alsted's Encyclopaedia septem tomis distincta (1630), the most famous and influential seventeenth-century writing of this genre. ${ }^{173}$ The Enclyclopaedia was divided into thirty-five books, to which thirty-eight tables were premised; in table XXXII, where theoretical disciplines were listed, Alsted introduced respectively metaphysics, pneumatics, physics and mathematics, which were all treated in the fourth tome with their ancillary disciplines. The list was almost identical to that in


absence of proper diacritics is, again, evidence of Locke's conceiving of the scheme as something for private use; I follow Locke's spelling faithfully.

${ }^{173}$ A Calvinist theologian, Alsted was the author of several works, mostly printed at Herborn, showing Ramist influences embedded with other elements such as millenarism and kabbalism (Clavis artis lullianae, 1609; Panacea philosophica, 1610; Metaphysica, tribus libris tractate, 1613; Methodus admirandorum mathematicorum, 1613; Theologia naturalis, 1615; Cursus philosophici encyclopaedia, 1620; Theologia casuum exhibens anatomen conscientiae et scholam tentationum, 1621; Encyclopaedia septem tomis distincta, 1630; Adnotationes in Pentateuchum, 1631;; Rudimenta linguae latinae, 1634; Prodromus religionis triumphantis, 1635; and Scientiarum omnium encyclopaediae, 1649 (a reworking of the Enclyclopaedia of 1630 in four volumes). 
Scheme 5: Alsted mentioned metaphysics in first place and physics in third, whereas Locke introduced respectively theology and $\varsigma \omega \mu \alpha \tau \iota \kappa \eta$. The list in Scheme 5 terminated with arithmetic and geometry; Alsted introduced 'Mathematica', which included 'Arithmetica', 'Geometria', 'Uranometria', 'Geographia', 'Optica' and 'Musica'. The third, fourth and fifth were included by Locke under $\Sigma \omega \mu \alpha \tau \imath \kappa \eta$.

In the thirteen book of the fourth tome of the Encyclopaedia, devoted to Physica, Alsted divided the latter into eight parts:

1) Physica generalis;

2) 'Uranologia' or doctrina de coelo;

3) 'Meteorologia', intended as the first branch of 'Mictologia' (the doctrine of mixed bodies);

4) 'Nerterologia' or the doctrine of minerals;

5) 'Phytologia', the first branch of the doctrine of animated bodies ('Empsychologia');

6) 'Zoologia' (the doctrine concerning animals in genere); 'Therologia' (the study of irrational animals) and 'Antropologia' (the doctrine of man);

7) 'Physiognomia' (the doctrine of those signa explaining natural bodies);

8) 'Cosmologia' or doctrina de mundo. ${ }^{174}$

Locke mentioned eight subheadings under $\Sigma \omega \mu \alpha \tau \imath \kappa \eta$; the first one, 'Y $\rho \alpha v o \lambda o \gamma 1 \alpha$ ', corresponded to Alsted's 'Uranologia'. In the Encyclopaedia, 'Uranologia' or 'Uranometria' represented the scientia sphaerae coelestis including both 'Astronomia' and 'Astrologia'. ${ }^{175}$ In Scheme 5, Locke introduced astronomy after

174 In Table xxxii, Alsted listed all the various branches of physics together: 'Physica generalis', 'Uranologia' or 'doctrina coeli'; 'Somatologia'; 'Stoecheiologia' or 'historia elementorum'; 'Mictologia' or the study of mixed bodies; 'Meteorologia'; 'Oryctologia' or the study of fossils, to which 'Lithologia' and 'Metallographia' were linked; 'Botanica'; 'Zoologia' and the annexed 'Therologia', or the study of the various species of animals; 'Anatomia', 'Sphigmologia', 'Pathologia' and 'Physica', all relating to medicine; 'Ornithologia', Ichtiologia', 'Bucolica' or the study of brutes, 'Antropologia' and 'Cosmologia'.

${ }^{175}$ Alsted, Encyclopaedia, tome III, b. xvii, pars 2, ch. 1, 689. 'Uranometria' was the third of the mathematical disciplines listed in table XXXII, after 'Arithmetica' and 'Geometria'. 


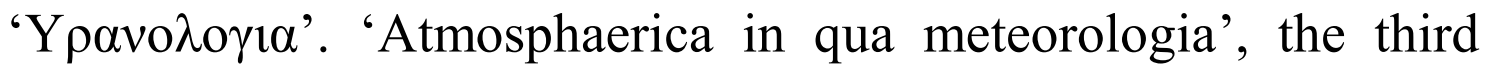
subheading under $\Sigma \omega \mu \alpha \tau \imath \kappa \eta$, corresponded to the third part of Physica in the Encyclopaedia, including meteorology. ${ }^{176}$ The other subheadings did not have an immediate correspondence to the subsequent parts of physics in the Enclyclopaedia. Locke had preferred not to depart too much from the Aristotelian model he had followed in his previous schemes, which was still visible in spite of the different terminology he had adopted. I will return to $\Sigma \omega \mu \alpha \tau \iota \kappa \eta$ and its subheadings later; for now, I will focus on the list of theoretical disciplines at the beginning of Scheme 5 to allow the differences with Alsted's list emerge in detail.

As has already been said, Alsted mentioned metaphysics in the first place, whereas Locke chose theology; however, in Some Thoughts concerning Education he would speak of metaphysics as the first part of physics, concerning the study of the nature and properties of spirits. ${ }^{177}$ Clearly, Locke had changed his manner of conceiving metaphysics and its location in the system of sciences over time. In the classification written in 1681 Metaphysica was the first of the various branches of knowledge, being placed before Theologia (in conformity with Suárez's teaching), whereas in the classification of 1687 and in the 'Division of the Sciences' at the end of the Essay metaphysics was not mentioned. In Some Thoughts it reappeared but in a subordinate position and with a content radically different with respect to the one which it had had in the classification of 1681 (the science inquiring into ens commune and its predicates).

The influence of William Ames, and puritan theology more generally, was probably at the root of these changes. This influence was already visible in the classification of 1681 with

${ }^{176}$ Alsted, Encyclopaedia, tome IV, b. xiii, pars. 3, ch.1, 700, and ch. 8, 704.

177 Locke, Some Thoughts, §190, 244-45: 'Natural Philosophy being the Knowledge of the Principles, Properties, and Operations of Things, as they are in themselves, I imagine there are Two Parts of it, one comprehending Spirits, with their Nature and Qualities; and the other Bodies. The first of these is usually referr'd to Metaphysicks: But under what Title soever the consideration of Spirits comes, I think it ought to go before the study of Matter and Body'. 
reference to Theologia, which was divided into two parts, speculative and practical. This distinction conformed to the teaching of Reformed theologians such as Amandus Polanus and Ames, ${ }^{178}$ whose treatises included a section dealing with doctrine and another with practice. They usually defined theology as a practical discipline in contrast with purely speculative sciences, following Ramus's teaching. ${ }^{179}$ Ames criticised the distinction between practical and speculative disciplines, and stigmatized metaphysics as vana et inutile: the differentiation between theology intended as the discipline investigating divine things through revelation, and metaphysics intended as the discipline inquiring into this same subject through the lumen naturale, was erroneous to his mind. Everything which could be known through natural light was known through revelation. ${ }^{180}$ Metaphysics was a redundant discipline, for there was no ground for any distinction between a natural and supernatural doctrine of God; the matters it inquired into could be adequately discussed in theology, logic, mathematics, or physics.

The priority which Locke attributed to Metaphysica in the classification of 1681, a priority which, nonetheless, gave him some difficulty, ${ }^{181}$ suggests he was following Ames's teaching only with reference to theology; the absence of metaphysics from the list of theoretical sciences in Scheme 5 showed he had

${ }^{178}$ Locke possessed Polanus's Partitiones theologicae (Basle, 1601: LJL, 2366) and Ames's Declaration of ye Witnesses of God (London, 1681: LJL, 84); he might have bought only those works which he could not easily find in Christ Church Library.

179 In his Commentariorum de Religione Christiana (Frankfurt, 1576), Petrus Ramus defined theology as 'the doctrine of living well'; his disdain for Aristotle was particularly apparent in the area of ethics. In his view, the ethics of the Bible owed nothing to Aristotle's ethics (cf. Ramus, Oratio de Professione liberalium artium, Paris, 1563).

180 See William Ames, 'Disputatio Theologica adversus metaphysicam', in Philosophemata, thesis 7, 111; compare, in the same volume, Technometria, §112, 32 .

${ }^{181}$ In 'Adversaria 1661', fos. 290-91 Theologia preceded Metaphysica, though it was numbered ' 2 ' and metaphysics ' 1 '; only in MS Locke c. 28 , fos. 157-58 did Metaphysica come before Theologia. 
reconsidered what role to attribute to the discipline in the light of Ames's criticism. The presence of Theologia in Scheme 5, as well as the absence of metaphysics, might be symptomatic of Locke's intention to emphasize the superiority of divine revelation with respect to natural light. Ames' teaching, but also Locke's burgeoning intellectual relationship with the Remostrant theologian Philippus van Limborch (an opponent of Spinozism) ${ }^{182}$ during his stay in Holland, might have played a relevant role in this regard. Alternatively, we might suppose that the theology introduced in Scheme 5 was natural theology, a hypothesis to which I will return in due course below.

In Some Thoughts, Locke declared that other names could substitute for the term Metaphysica (another symptom of his dissatisfaction with it). He might have been thinking of Pneumatica, the second discipline listed under Physica in Scheme 5, after Theologia. In his Encyclopaedia, Alsted characterized pneumatics as the scientia de natura spiritus; he defined it as a disciplina philosophica inquiring into the nature of particular spiritual entities (God, angels and anima separata), and distinguished it from metaphysics (the science investigating the ens generalissimus). ${ }^{183}$ Alsted's pneumatics was the science to which Locke was probably alluding in the 'Division of the Sciences' at the end of the Essay, where he referred to the knowledge of God, angels and souls as a subject pertaining to Physica; the preference he accorded to the term 'metaphysics' in Some Thoughts might simply be a concession to the prepossessions of the audience for which it was destined.

As regards $\sigma \omega \mu \alpha \tau \iota \kappa \eta$, the third topic in the list on p. 155r, the term somatica was sometimes used as synonymous with physica in Locke's time, as was the case in Stephen Chauvin's Lexicon

182 See Philippus van Limborch, Theologia Christiana ad praxin pietatis ac promotionem pacis christianae unice directa (Amsterdam, 1686), where Spinoza's view on miracles was criticized.

${ }^{183}$ Alsted, Encyclopaedia, tome IV, b. xi, pars 1, ch. 1, 631. 
rationale which appeared in Rotterdam in $1692 .{ }^{184}$ The Huguenot savant Chauvin immigrated to Rotterdam in 1685; Locke spent most of his time in Rotterdam from 1683 to 1689, lodging with Benjamin Furly (whose sympathies with dissenters and refugees are well documented, as in his correspondence with Locke).

The Lexicon's terminology was not, however, a source of Scheme 5. Locke did not use the terms Physica and $\Sigma \omega \mu \alpha \tau \iota k \eta$ as perfect synonyms, for the latter corresponded only to physica specialis in his scheme: he wished to distinguish between Physica intended as a broad theoretical discipline, and $\Sigma \omega \mu \alpha \tau \iota \kappa \eta$, corresponding to one of its branches. A new concept of physica generalis, encompassing incorporeal beings, emerged from the inclusion of theology and pneumatics in the list at the beginning of Scheme 5. This was essentially what Alsted had affirmed in his Enclyclopaedia: 'Physica universalis, seu generalis, late sumto vocabulo, est rerum naturalium scientia, sive illae incorporeae sint, sive corporeae: stricte, est scientia corporis naturalis in genere ${ }^{186}$ In the first, broad sense, physica generalis was to be conceived of as the science concerning those principles and affections which were common to both spirits and natural bodies, that is as a discipline including both pneumatica specialis (the discipline investigating the nature of created and uncreated spirits) and physica specialis; likewise [Alsted had continued] physica specialis should be divided into pneumatologia, or

184 See Stephen Chauvin, Lexicon rationale sive thesaurus philosophicus (Rotterdam, 1692; 1713²). Chauvin divided theoretical philosophy into 'Pneumatica', 'Somatica' or physics, and 'Ontosophia' or metaphysics; pneumatics, the science concerning spirits, was sub-divided into 'Theologia', 'Angelographia' and 'Psychologia'. See ibid., s.v. 'Philosophia'. Chauvin's terminology was not new, stemming from Otto Casmann.

185 The second edition of Chauvin's Lexicon showed his appreciation of Locke's Essay: under the entry for 'Cognitio', Chauvin added a two-column summary of Locke's Essay ('Anglus quidam vir illustris') to the explanation of the Scholastic and Cartesian theories of knowledge (Chauvin, Lexicon philosophicum, s.v. 'Cognitio', 113-14).

${ }^{186}$ Alsted, Encyclopaedia, tome IV, b. xii, pars 2, ch.2, 642. Italics in the text. 
scientia spiritus, and somatologia, or scientia corporis. Hence, somatologia corresponded in the Encyclopaedia to the investigation of substantia corporea; Locke preferred the Greek term $\sigma \omega \mu \alpha \tau \iota \kappa \eta$, but the idea was the same. The object of Physica was to be conceived of as extending beyond corporeal things, so as to include spirits (a subject pertaining to Theologia in Locke's previous classifications); physica generalis was to be intended as the speculative part of physics inquiring into the nature, constitution and properties of both material and spiritual entities. We may now better understand why the list of topics located at the very end of the last adversaria, D, was probably added later, perhaps at the time in which Locke was composing Scheme 5: various topics in the list (such as 'Spiritum' and 'Mira') referred to incorporeal beings as objects to be considered by 'Historica Physica'. The list also incorporated two terms, 'Oupavik $\alpha$ ' and 'Hydrographica', which reappeared in Scheme 5 under $\Sigma \omega \mu \alpha \tau \iota \kappa \eta$ '

Locke's evident knowledge of the Encyclopaedia might have its roots in a prior knowledge of Ames's writings: the interest in Puritan theology manifest in the classification of 1681 might have led Locke to investigate the Encyclopaedia, which had powerfully influenced Ames's Technometria. Both Ames's technologia (the theory or study of art) and Alsted's (the doctrina de proprietatibus, ordine et numero disciplinarum) represented a development of Ramus's technology (the art of properly arranging the contents of the curriculum); ${ }^{187}$ the four praecognita omnium disciplinarum which Alsted introduced in the first tome of his Enclyclopaedia as the respective objects of 'Hexilogia', 'Technologia', 'Archeologia' and 'Didactica' reappeared in Ames's Technometria. ${ }^{188}$ Besides, both Alsted and Ames insisted

${ }^{187}$ On the term 'technology' see C. H. Lohr, "Technologia": the Calvinist Theory of Science in the Reinassance', in G. Piaia (ed.), La presenza dell'aristotelismo padovano nella filosofia della prima modernità (Rome, 2002), 123-32; K. L. Sprunger, 'Technometria: A Prologue to Puritan Theology', Journal of the History of Ideas 29 (1968): 115-22.

${ }^{188}$ See Ames, Technometria, §90, 86. On the relationship between Ames and Alsted, see L. W. Gibbs's Introduction to Technometry, (Philadelphia, 1979), $30 \mathrm{ff}$. 
on the unity of all knowledge: the Encyclopaedia was conceived of as the systema omnium systematum, the Technometria as the instrument to acquire Pansophia, i.e. the knowledge of the ends of the arts intended as a cognitio emanating from God and returning to him in the form of eupraxia. ${ }^{189}$ Several other aspects too, such as the importance attributed to didactics and mechanical arts, were shared in common by Alsted and Ames's works. Alsted in particular published a considerable number of works with the purpose of reforming early modern scholarship and education. He was Comenius's teacher at Herborn and strongly contributed to shaping his project of educational reform, a subject on which Locke reflected deeply during his time in Holland. Besides, Alsted's Enclyclopaedia influenced Comenius's pansophic ideal of a unique sapientia reconciling the various branches of knowledge, a 'Christiana Philosophia' conceived of as a viva universi imago. Comenius invoked the Biblical commonplace that God had ordered the world according to number, measure, and weight to herald a pansophic encyclopedia, which would unite natural philosophy and theology. ${ }^{190}$ The list of disciplines which Locke grouped under Physica in Scheme 5 seemed to be inspired by this same ideal, going beyond the barriers of the scholastic ordo scientiarum.

Locke's attention might have been caught by Alsted's Encyclopedia when he was in Rotterdam hosted by Benjamin Furly. The latter's library contained two works by Alsted, one of

${ }^{189}$ Ames, Technometria, §89, 85. Ames defined eupraxia as regularis agentis in agendo motus (Technometria, §13, 6). Eupraxia was the end of all disciplines, not only of the practical ones; the distinction between practical and theoretical disciplines was criticized in $\S 88,26$. Ames's enumerated six basic arts, corresponding to six kinds of eupraxia and six aspects of human existence: logic, grammar, rhetoric, mathematics, physics and theology. They represented the various links of a circular chain, starting with the comprehension of the individual arts and terminating in God.

${ }^{190}$ Cf. J. A. Comenius, Pansophiae Prodromus, In quo admirandi illius \& vere incomparabilis Operis, Necessitas, Possibilitas, Utilitas, solide, perspicue, \& eleganter demonstratur (London, 1639), sec. 40. Locke possessed Comenius's Physicae ad lumen divinum reformatae synopsis ( $L J L$, no. $819 \mathrm{~b}$ ), as well as various editions of his Janua linguarum ( $L J L$, nos. 817-19a). 
which echoed the contents of the Encyclopaedia in some respects. ${ }^{191}$ Furly himself came into close contact with Pansophism. ${ }^{192}$ Locke's friendship with Mercurius van Helmont, and his sharing the latter's interest in Kabbalah and millenarism are further elements to be considered, given the importance of Alsted's work on these topics. ${ }^{193}$

All this being said, it is also possible that it was Boyle who introduced Locke to the Encyclopaedia, which he probably possessed and with which he was surely well acquainted. In his New Pneumatical Experiments about Respiration (1670), Boyle had characterized void as 'absence of common air', so as to deprive it of any ontological status. This conceptual move enabled him to skirt what he considered to be the dangerous

${ }^{191}$ See Bibliotheca Furliana sive Catalogus Librorum honoratissimi et doctissimi Viri Benjamin Furly (Rotterdam, 1714), no. 14, 97, which refers to Alsted's Lexicon Theologicum (Hannover, 1620) and no. 170, 253, which refers to his Methodus admirandorum mathematicourum (Herborn, 1641). The various sections of the Methodus (Mathematica generalis, Arithmetica, Geometria, Cosmographia, Uranoscopia, Geographia, Optica, Musica, Architectonica) recall the internal divisions of the Encyclopedia.

${ }^{192}$ Furly's library showed his interest in the work of German mystics, including Jacob Boehme and Francis Mercurius van Helmont; through van Helmont, Furly came into contact with the mystical German theologian Christian Knorr von Rosenroth, the author of Kabbala Denudata. The latter was the leading figure of a pansophicalkabbalistic group in the court of Count Christian August von Pfalz-Sulzbach, that regarded the reconciliation of the Kabbalah with the Christian dogma as its primary duty. Rosenroth published his Kabbala with the hope of advancing universal knowledge; a letter from him to Locke concerning the Abregé of the Essay is to be found in Corr., iii, 399-405, and was probably given to Locke by van Helmont. Among Locke's papers there are notes (entitled 'Caballa [16] $\underline{88}$ ' (Bodl. H\&L, 558)) on chapter 3 of Rosenroth's Adumbratio Kabbalae Christianae, issued in 1684; another paper, 'Lexicon Syncatabasis $7 \underline{\text { 88' }}$ (Bodl. MS. Locke c. 27, ff. 79-80), contains the definitions of terms taken from Rosenroth's Adumbratio. On Locke and van Helmont, see A. P. Coudert, 'John Locke and Francis Mercurius van Helmont', in Everything Connects: In Conference with Richard H. Popkin: Essays in His Honor, ed. J. E. Force and D. S. Katz (Leiden, 1999), 87-113.

${ }^{193}$ See Alsted's Diatriba de mille annis apocalypticis, non illis Chiliastarum \& Phantastarum, sed B B. Danielis \& Johannis (Frankfurt, 1627). Locke took some notes regarding millenarism from Helmont's writings. See John Marshall, John Locke: Resistance, Religion and Responsibility (Cambridge, 1994), 601-2. 
theological implications of giving a non-material entity, such as More's Spirit of Nature, an absolute existence. The interpretation of void as privation was in Alsted's Enclyclopaedia, ${ }^{194}$ though of course Boyle departed from Alsted's denial of its existence. There is evidence that Boyle took some quotations from the book, which was probably in his library. ${ }^{195}$ Boyle might have shown the Encyclopaedia to Locke several years before the composition of Scheme 5, yet it seems not to have exerted a peculiar influence on his previous classifications; it may be that Locke returned to Alsted's work at a moment in which his interest in theology had grown significantly, influencing also his manner of conceiving physics. A fully materialistic understanding of the latter's object appeared inadequate when he was penning Scheme 5; the Encyclopaedia was a fruitful source for devising an alternative, pansophic type of physics.

Let us go back to the scheme of $\Sigma \omega \mu \alpha \tau \imath \kappa \eta$, where some similarities between Locke and Alsted's divisions of physics have already been noted. The scheme was also evidence of important differences from that model. Alsted's terminology was not always attractive to Locke. The Encyclopaedia, for instance, contained the term 'Botanica', whereas Locke preferred 'Vegetabilia' which was common in translations of Aristotle. Alsted used the term 'Zoologia', whereas Locke preferred 'Animalia', though he had

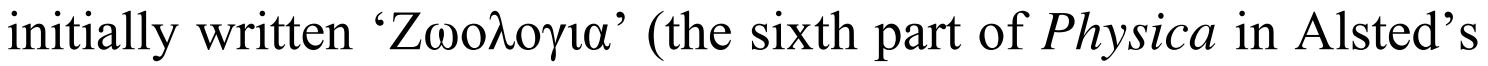
Enclyclopaedia, and the sixth subheading under $\Sigma \omega \mu \alpha \tau \imath \kappa \dot{\eta}$ in Scheme 5).

After uranology, astronomy and meteorology, Locke introduced 'Hydrographia' and 'Geographia', respectively the

${ }^{194}$ Alsted, Encyclopaedia, tome IV, bk. 13, pars 1, ch. 11, sec. 8, 682.

195 See The Early Essays and Ethics of Robert Boyle, ed. J. T. Harwood (Edwardsville, IL, 1991), xxii; M. Hunter, 'How Boyle Became a Scientist', History of Science 33 (1995): 78; J. E. Jenkins, 'Arguing about Nothing: Henry More and Robert Boyle on the Theological Implications of the Void', in Rethinking the Scientific Revolution, ed. Margaret J. Osler (Cambridge, 2000), 177-80. 
fourth and fifth subheading under $\Sigma \omega \mu \alpha \tau \imath \kappa \eta$; Alsted considered 'Geographia' as one of the mathematical disciplines, and 'Hydrographia' as one of his branches. Some deletions reveal that Locke had initially written 'Geographia' before 'Hydrographia', but he had subsequently inverted them so as to respect the order of the four elements: the Aristotelian model to which his previous schemes of Physica conformed was only partially abandoned in Scheme 5, confirming Locke's somewhat conservative attitude towards that framework.

The sixth subheading, 'Fossilia', substituted the deleted


'Vegetabilia', were accompanied by some items in faint handwriting. The topics pertaining to the first were respectively 'Metalla', 'Semimetalla', 'Sales', 'Succi concreti', 'Lapides' and 'Boli'; those pertaining to 'Vegetabilia' were 'Arbores', 'Fructices' and 'Herba'. The same items reappeared on the following page (f. $155 \mathrm{v}$ ), where several of them had been deleted: probably Locke had initially written them there and later added them to the previous page. The eighth subheading under $\Sigma \omega \mu \alpha \tau \iota \kappa \eta '$, 'Animalia', substituted the deleted 'Mineralia Fossilia


line (the penultimate of p. 155r). Minerals, fossils, animals and plants were usually treated together in sixteenth- and seventeenthcentury books on mineralogy (those by Aldrovandus and Gessner, for instance); their repetition (for they had been already introduced as separate subheadings) suggested Locke was seriously perplexed about the way of ordering the object of physica specialis. He was unsatisfied both with Alsted's innovative model and with the older Aristotelian model; the latter seemed however to have exerted a residual influence, as shown by the subsequent page of the scheme (155r).

As for $\alpha v \tau o \mu \alpha \tau \alpha$, the term recalled Descartes's view of animals as simple machines, without cogitatio and souls. Locke's account of idiots in the second book of the Essay was bound up

196 The proper diacritics ( $\alpha$ $\tau$ ó $\mu \alpha \tau \alpha)$ again are absent. 
with contemporary debates about the status of animals, which were particularly heated in France; the author at the centre of the French debate, the Jesuit scientist Ignace Gaston Pardies, ${ }^{197}$ rejected Cartesian automatism, claiming that animals had some aptitude for reason but that humans alone were able to exercise the higher operations of the mind. Locke mentioned Pardies in his notebooks, but where the latter identified these higher operations with innate common ideas, Locke took an empirical approach. In the Essay, his final word on the place of brutes on the scale of beings was that they were not able to abstract; the allocation of

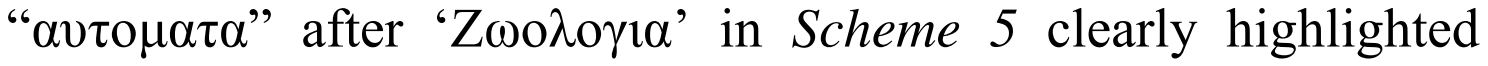
Locke's rejection of Descartes's view.

At the top of $f .155 \mathrm{v}$, Locke reintroduced the subheading 'Animalia' followed by the names of four species, respectively 'Aquatilia', 'Volucres', 'Reptilia' and 'Quadrupides'. 'Insecta' and 'Amphybia', which were in the previous schemes, were not cited. The presence of several deletions seemed to indicate Locke was uncertain about the best order and terminology to adopt:

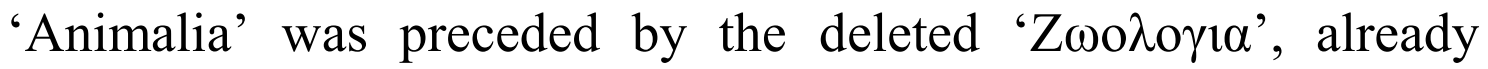
present on the previous page. 'Volucres', which was also in Schemes 2 and 4, substituted the deleted 'Volatilia'; 'Quadrupidia' and 'Aquatilia' substituted respectively the deleted 'gressilia', which was in all the previous schemes, and 'Natantia', which was only in Scheme 1. The order of the species, too, was different with respect to the other schemes, being inspired by the account of the creation in Genesis (water creatures and birds on the fifth day; creeping animals and other terrestrial animals on the sixth day). What remained constant was Locke's refusal of the dichotomy between terrestrial and aquatic animals, already apparent in his earlier schemes.

'Homo' was not one of the subheadings. The various topics listed under it in the previous schemes, most of which referred to the faculties of the mind, were not cited. 'Homo' was included

${ }^{197}$ I. G. Pardies, Discours de la connoissance des bestes (Paris, 1672: LJL, no. 2193). 
under 'Animalia' on f. $155 \mathrm{v}$, both as the first of the various species, and as the last of them. In the first occurrence, the term had been deleted: probably Locke had initially thought of dividing animals into rational and irrational, as in several Aristotelian classifications, ${ }^{198}$ but he preferred to follow the account of Genesis (man as the last of the created species), which bespeaks once more the attention he devoted to theology in Scheme 5.

After 'Animalia', Locke had written, and then deleted, 'Vegetabilia' with its three species, respectively 'Arbores', 'Fructices' and 'Herba' (which were also on p. 155r, where they had probably been copied after having been written on $\mathrm{f} .155 \mathrm{v}) .{ }^{199}$ The three species represented the classic divisions of botany, which could be traced back to Theophrastus and were still widely used in the seventeenth century. This was the first time that something had been added under 'Vegetabilia' in Locke's schemes of Physica. In 1686, Jean Le Clerc had asked him to review John Ray's Historia plantarum (1686), knowing of his interest in botany. ${ }^{200}$ The addition might be linked to this episode.

The work of Ray, which marked an important step towards modern botanic taxonomy, was well known to Locke, as was the theological perspective which supported it. A Cambridge natural historian and divine, Ray perceived clear evidence of supernatural order in the intricate adaptations of plants and animals to their environments; he was one of the preeminent exponents of the English natural theology tradition together with Richard Bentley, William Derham and William Whiston. They all intended to provide support for the argument from design through the

198 Alsted divided animals into irrational ('Bestia') and rational ('Homo'): see Encyclopaedia, tome IV, b. 13, pt. vi, ch.3, 745. 'Therologia' preceded 'Antropologia'.

199 The many deletions on $\mathrm{f} .155 \mathrm{v}$ suggested Locke might have used it as a draft.

${ }^{200}$ The review was published anonymously in Bibliothèque universelle et historique 3 (1686), 1-17. Regarding its attribution to Locke, see Rosalie Colie, 'John Locke in the Republic of Letters', in Britain and the Netheriands, ed. J. S. Bromley and E. H. Kossmann (London, 1960), 111-29. 
scientific investigation of nature. This was the focus of the annual series of Lectures promoted in Boyle's name from 1691, which had to render manifest how the 'Book of nature' could prove and teach the tenets of Christianity. ${ }^{201}$ Newton's famous pronouncement in the second edition of his Principia Mathematica (1713), as well as his (fractious) correspondence with Bentley in the early 1690s, went in this same direction: the order manifest everywhere in the universe was clear proof of the existence of a creator and of his design. The theology which Locke introduced in the list on $\mathrm{f}$. 155r might have been conceived by him as the natural theology hymned by Boyle in the Christian Virtuoso: ${ }^{202}$ a 'true natural theology, 203 for Boyle should include an investigation of the 'pneumatical world' and make use of the whole sphere of 'experience', both natural and supernatural. ${ }^{204}$ If the theology in Scheme 5 was only natural, revealed theology was left out of the scheme. The exclusion of theology from the 'Division of the Sciences' at the end of the Essay might have been anticipated in this way in Scheme 5.

After 'Vegetabilia', Locke rewrote 'Fossilia' with the various topics which followed it on the previous page. He had initially written 'Mineralia' instead of 'Fossilia', but had then deleted it: 'Mineralia' had been rewritten after 'Semi metalla', as synonymous with it. 'Semi metalla' was a term also used by Boyle to identify those 'fossils' which, 'though of affinity to

${ }^{201}$ The English physico-theology movement was given a public forum in the Boyle Lectures founded in 1692; the most influential published Boyle Lectures in natural theology were those delivered by William Derham in 1711 and 1712, published as Physico-Theology in 1713. There were several works by Ray in Locke's library: see LJL, no. 2444-2447.

${ }^{202}$ According to Anstey, the notes in MS. Locke c. 27, fos. 67-68, entitled 'Boyle, Observations on his Treatise $\underline{81}$ ', would refer to a manuscript draft of The Christian Virtuoso, published in 1691. See Anstey, 'The Christian virtuoso and John Locke', in On the Boyle 2 (1998): 5-7. Therefore, Locke would have known the work before its publication.

${ }^{203}$ Boyle, The Christian Virtuoso. Appendix to the First Part, in Works, vi, 705-6.

${ }^{204}$ Boyle, The Christian Virtuoso. Second Part, in Works, vi, 751. 
metals, are wont to be distinguished from true metalline ores'. ${ }^{205}$ 'Minerals' was a term frequently used by Boyle, sometimes to encompass all inorganic bodies apart from metals, sometimes as synonymous with 'Fossilia' ${ }^{206}$ Locke's hesitation to abandon the old term 'Fossilia', which since Agricola had been used to refer to all inorganic bodies, is symptomatic of his linguistic caution: a passage in the "Advertisement to the Reader" which he wrote for Boyle's General History of the Air showed he considered 'mineral' as a term in need of clarification when intended, as Boyle sometimes did, as an equivalent for 'Fossilia'. 207

The six topics listed under 'Fossilia' did not exactly correspond to the various species of fossils catalogued in sixteenth and seventeenth-century books on mineralogy, deeply influenced by Agricola. Following Dioscoride, Agricola introduced four species of fossils, respectively 'Terrae', 'Succi concreti', 'Lapides' and 'Metalla', a division which also Cardano and Falloppio had adopted. In his Musaeum metallicum, Aldrovandus preferred a different ordering, 'Metalla', 'Terrae', 'Succi concreti' and 'Lapides', which he considered as more Aristotelian, for metals were the most known and used species of fossils. In his Epitome, Sennert introduced five species, respectively earth, salt, bitumen and sulphur, stones and metals; the six species Locke mentioned in Scheme 5, as well as their order, seemed to refer to a different, more advanced model. They recalled those which Herman Boerhaave would introduce in his Elementa Chemiae, ${ }^{208}$ namely 'Metalla', 'Salia', 'Sulphurea',

${ }^{205}$ Boyle, A Previous Hydrostatical Way of Estimating Ores, in Works, v, 493.

${ }^{206}$ See for instance Boyle, The Sceptical Chymist, in Works, i, 487: 'fire is not a universal analyzer of all mixt bodies,... of metals and minerals'; Of the Unsuccessfulness of Experiments, in Works, i, 322: 'minerals of differing kinds, as marchasites and metals'.

${ }^{207}$ See Boyle, The General History of the Air, in Works, v, 610: 'under the title of mineral substances are comprehended earth, and all other fossils, to avoid multiplying of articles'.

${ }^{208}$ See Boerhaave, Elementa chemiae, quae anniversario labore docuit, in publicis, privatisque, scholis, Hermannus Boerhaave (2 vols., Leiden, 1732). 
'Lapides', 'Terrae' and 'Semimetalla'. On p. 155v of Scheme 5, Locke had initially written, and then deleted, 'Terrae' instead of 'Boli' (which in the Elements would be mentioned as a species of medicinal earth). ${ }^{209}$ The similarity with Boerhaave's ordering is suggestive. He was active in Leiden, one of the towns which Locke visited during his stay in Holland, ${ }^{210}$ the wide scientific milieu with which he came into contact during his exile, the same milieu in which Boerhaave's ideas germinated, might have exerted some influence on him, though the different cataloguing of fossils in chap. viii of the Elements ('earth, stones, metals, minerals and other fossils'), if it was Locke's work, is more reminiscent of Agricola's classifications and may show that this influence did not last. ${ }^{211}$

There was no mention of 'Sensus', the last subheading in Locke's previous schemes. Some of the topics collected under it in those schemes were listed at the bottom of f. $155 \mathrm{v}$ and at the top of f. 156r. Each was marked by a number: '1 Motus', ' 2 ' Visus Lux Colores optica tinctoria [perspectiva deleted] gotica', '3 Auditus Soni', '4 Gustus Sapores', '5 Olfactus Odores'. Touch and tactile qualities were not cited. 'Motus' was separated from 'Mechanica'. Its allocation before sense objects suggested it might refer to those 'Motions of our Spirits, or Alterations of our Bodies' by which, Locke affirmed in the Essay, 'we come to have any Sensation by our Organs, or any Ideas in our Understandings'. ${ }^{212}$ 'Perspectiva' might be a reference to Baroque perspective tools such as the anamorphosis, of which he spoke in the Essay when considering the causes of confused ideas; ${ }^{213}$ also

${ }^{209}$ Locke, Elements, 428. In Boyle's Specimen de Gemmarum origine et virtutibus (1680), 56, boli were characterized as 'mineralia apertae texturae'.

${ }^{210}$ See Woolhouse, Locke, 203.

${ }^{211}$ Locke, Elements, 428.

${ }^{212}$ E I.i.2, 43.

${ }^{213}$ E II.xxix.8, 365-66. The anamorphosis required the viewer to use special devices to reconstitute the image; Locke introduced the example of a draught and a cylindric mirror. 
'gotica' might refer to Baroque art (and in particular to Baroque architecture, as with the 'props and buttresses' mentioned in the Essay). ${ }^{214}$ 'Medicina', 'Veterinaria', and 'Mechanica' concluded the outline of $\Sigma \omega \mu \alpha \tau \imath \kappa \eta$; 'Veterinaria', which was already in some of the adversaria, recalled Locke's interest in husbandry as well as one of his activities during his stay in Holland, the rearing of sheep $^{215}$.

The first datum which emerges from a comparison between the content of physica specialis in Scheme 5 and the previous schemes is the substitution, or attempted substitution, of the various subheadings which organised the latter with something else. The Aristotelian divisions of physics were replaced by the names of the corresponding sciences: uranology and astronomy substituted respectively 'Mundus sive Universum' and 'Coelum'; the four elements were replaced by 'Atmosphaerica', 'Hydrographia' and 'Geographia'; an attempt to replace

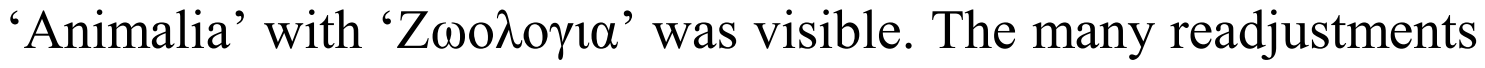
under $\Sigma \omega \mu \alpha \tau \imath \kappa \eta$ showed Locke's dissatisfaction with the Aristotelian model, and his desire to render justice to the specificity and autonomy acquired by various scientific disciplines. 'Sensus' was not present, probably because of the impossibility of substituting the term with the name of one single science; 'Corpus Humanum' was replaced by 'Medicina'. No mention was made of its branches: their absence, as well as that of other minor topics (such as tactile qualities), suggested Locke was more concerned with revising the general architecture of physica specialis than with its single items. The difficulties he encountered in this attempt were apparent, given the many deletions: Locke was probably dissatisfied with the scheme,

${ }^{214}$ E I.iv.25, 102: 'But in the future part of this Discourse, designing to raise an Edifice uniform, and consistent with it self...I hope, to erect it on such a Basis, that I shall not need to shore it up with props and buttresses, leaning on borrowed or begg'd foundations'.

${ }^{215}$ Locke donated some of his sheep to Edward Clarke: see Corr., iii, 351. His library included several almanacs, a precious source of information for husbandry (see LJL, Appendix V, 292, s.v. 'Almanacs'). 
which represented a sort of compromise between the old and the new. This might explain why he did not develop the content of $\varphi v \sigma \imath \kappa \eta$ in the 'Division of the Sciences' at the end of the Essay into more detailed schemes: he might have still been wrestling with how to systematise the contents of physica specialis properly.

The classification of 1687 seemed to have been a preparatory scheme for the 'Division of the Sciences', which included respectively $\varphi v \sigma \imath \kappa \dot{\eta}, \Pi \rho \alpha \kappa \tau \imath \kappa \eta$ and $\varsigma \eta \mu \iota \omega \tau \iota \kappa \eta '$. Physica occupied the first place, as in Scheme 5, and was characterized as a speculative science. Its object was described as follows:

The Knowledge of Things, as they are in their own proper Beings, their Constitutions, Properties, and Operations, whereby I mean not only Matter, and Body, but Spirits also, which have their proper Natures, Constitutions, and Operations as well as Bodies. This in a little more enlarged Sense of the Word, I call $\varphi v \sigma \iota k \eta$, or natural Philosophy. The end of this, is bare speculative Truth, and whatsoever can afford the Mind of Man any such, falls under this branch, whether it be God himself, Angels Spirits, Bodies, or any of their Affections, as Number, and Figure, etc.

This passage shed further light on the elaborate architecture of Scheme 5: $\varphi v \sigma \imath \kappa \eta$ was to be conceived of in a 'more enlarged sense', that is to say as synonymous with the new physica generalis devised in Scheme 5, including pneumatica. Locke's earlier schemes of physics reflected his endorsement of Boyle's mechanism and his materialistic understanding of bodies; in particular, Scheme 2 revealed the great authority which he conferred on Boyle in determining the content of physica generalis. Scheme 5 might still appear more or less coherent with Boyle's teachings in the Christian Virtuoso: Boyle was familiar with pansophism and was deeply influenced by Comenius's ideals of universal learning during his life. ${ }^{216}$ However, the

${ }^{216}$ The inclusion of a letter by Benjamin Worsley to Hartlib in Boyle's General History of the Air confirmed this; the letter concerned the celestial influences on the earth (as well as on the souls of mixed bodies, including men's souls). Besides, in a typically Comenian fashion Worsley pointed out that astrology, alchemy, medicine and 
attribution of bodies to spiritual beings in the 'Division of the sciences' suggests another influence, that of Platonism: it was More, arguing against Descartes, who had insisted that God had to be somehow extended in order to communicate motion to matter. In The Immortality of the Soul, More affirmed that God's supreme perfection implied his omnipresence and ubiquity, which could only be conceived of as an extended 'Divine Amplitude'. ${ }^{217}$ This should not, More continued, be confused with bodily extension, for extended bodies were divisible and penetrable, whereas God and finite minds were indivisible and impenetrable. Following More, Newton insisted that every being, including God and the created minds, could not exist if not related to space in some way. ${ }^{218}$ Similarly, in the Essay Locke declared that God 'fills Immensity', and that it was an excess of materialism (and dogmatism) to believe that "where there is no Body, there is nothing'.

Like More, Locke was careful to insist that, though extended, God was not material. In correspondence with Limborch in 1697, he recurred to More's argument of God's ubiquity in space to demonstrate His uniqueness. ${ }^{220}$. Clearly, he had changed his mind with respect to the past: the materialistic understanding of bodies which Scheme 1 highlighted, perhaps in direct opposition to

theology were closely connected: probably Boyle agreed with him. See A. Clericuzio, 'New Light on Benjamin Worsley's Natural Philosophy', in Samuel Hartlib and Universal Reformation: Studies in Intellectual Communication, ed. M. Greengrass, M. Leslie, and T. Raylor (Cambridge, 1994), 236-46.

${ }^{217}$ Henry More, The Immortality of the Soul (Dordrecht, 1987), 33.

${ }^{218}$ Newton, De gravitatione, in A. Janiak ed., Newton: Philosophical Writings, (Cambridge, 2004), 25. See also the discussion of space and time in the Scholium to the Principia, and the discussion of God in the General Scholium added to the 1713 edition of the Principia.

${ }^{219}$ E II, xv, 3, 197.

${ }^{220}$ The combined influence of More and Newton was apparent in Locke's correspondence with Limborch of 1697, where he introduced the notion of God's omnipresence in pure space. See Corr., vi, appendix II, 783-87. 
More's notion of a Spirit of Nature, had been overcome by a Morean understanding of extension, one implicit in the content of physica generalis in Scheme 5. An important role in this regard might have been played by the Platonism of Damaris Cudworth, or by Locke's Hollandish acquaintances, ${ }^{221}$ or even by Newton (though Locke met him only in 1689). However, the antiCartesian view of space which emerged from the journal note of 16 September 1677 suggests that Locke was already rethinking his concept of extension in those years. ${ }^{222}$

Theology was not mentioned in the 'Division of the Sciences': at the time of writing the Essay, Locke had become convinced that its object ranged far beyond the various sciences, even beyond the natural theology of Scheme 5. A scheme of Theologia he wrote in $1694^{223}$ highlighted how much relevance he attributed to a physico-theological investigation of nature, for it included topics ('Materia', 'Homo' and 'Sistema nostrum') pertaining to Physica in the previous classifications. ${ }^{224}$ It also incorporated 'Ethica', which was in keeping with Locke's intention to bring together all the various sciences into a single one, and 'Revelatio', which was evidence of his including both natural and revealed theology. In Of the Conduct of Understanding, Locke emphasized the priority of theology with respect to the other sciences - it was 'incomparably above all the rest'-insisting on

${ }^{221}$ See V. Nuovo, 'Reflections on Locke's Platonism', in Christianity, Antiquity and Enlightenment: Interpretations of Locke (Dordrecht, 2011), 163-180.

${ }^{222}$ See note 141 above.

223 'Adversaria Theologica 94', ff. 1-7, printed in Victor Nuovo (ed.), John Locke: Writings on Religion (Oxford, 2002), 21-33.

${ }^{224}$ In a letter to Limborch, Locke remarked on the importance of approaching difficult theological questions 'physically': see Locke to Limborch, 29 October 1697, Corr., vi, 783-87); the theological question the latter was inquiring into, concerning the way to prove God's uniqueness, could be better approached for Locke in physical terms: 'the mind must be raised to a somewhat higher level and separated from the ordinary manner of philosophizing if anyone wants to prove it philosophically or, if I may speak thus, physically'. 
its all-encompassing nature as well as on the significant contribution which it offered to broadening man's understanding:

This is that noble study which is every mans duty and every one that can be called a rational creature is capable of. The workes of nature and the words of the Revelation display it to mankinde in Characters soe large and visible that those who are not quite blind may in them read and see the first principles and most necessary parts of it and from thence as they have time helps and industry may be inabled to goe on to the more abstruse parts of it and penetrate into those infinite depths filld with the treasures of wisdome and knowledg. This is that Science which would truly enlarge mens minds were it studyed or permitted to be studyed every where with that freedom, love of truth and charity which it teaches, and were not made contrary to its nature the occasion of strife faction, malignity and narrow impositions. ${ }^{225}$

The pansophism sketched in Scheme 5 found its complete formulation in the Conduct. For among the benefits deriving from the study of theology would be a better understanding of the secret workings of nature.

\section{§3. Conclusion}

Locke might have conceived his schemes of Physica as maps of his own studies, yet they surely represented more than this. The schemes progressively became a sort of diary where he noted down his experiences and interests, as well as an instrument for rethinking the content and scope of natural philosophy. The Aristotelian model, and the worldview to which it gave form, represented an important legacy which Locke, as many of his contemporaries, had deeply absorbed. This model was still only partially abandoned in Scheme 5. The theoretical nature which he attributed to physics in the latter and in the Essay, which was obscured in the earlier classification by the location of Physica after practical sciences, illustrated the recovery of the fundamental premise of that model, the idea of scientia as

${ }^{225}$ See Locke, Of the Conduct of the Understanding, ed. P. Schuurman (University of Keele, 2000), §23, 193. 
deductive-demonstrative knowledge distinct from that obtainable through the empirical observation of nature. However, the privileged position attributed to Physica as the first of the various sciences in the Essay seemed to contrast with Locke's pessimism regarding the possibility of natural philosophy obtaining the status of a science. This contrast may be softened when considering that the Aristotelian ideal of a demonstrative knowledge served to mark the distance between the hypothetical knowledge obtainable through experiment and observation and the certain knowledge obtainable through a new, pansophic physics which did not rely exclusively on materialistic premises. Physics, intended as the science of material bodies, could not achieve the status of a science, Locke declared in the Essay, for it was impossible to obtain a certain, demonstrable knowledge of the nature of things. The Essay highlighted the contradiction between atomistic philosophy and certain knowledge: the mechanical worldview purported to explain all natural phenomena by the size, shape and motion of invisible particles of matter, yet these particles were not amenable to direct observation. Therefore physics was necessarily hypothetical. It was questionable whether certainty and explanation could be achieved by natural philosophy.

However, the Essay also indicated the way of overcoming this contradiction: the objects of physics should not be understood exclusively in materialistic terms. The many hypotheses which Boyle advanced in his Cosmical Qualities regarding the action of 'unheeded agents' (but also the 'heteroclite effluviums' he spoke of in his Suspicions about some hidden qualities in the air of $1674)^{226}$ might have played an important role in Locke's

${ }^{226}$ In the Suspicions, Boyle argued that the air might contain several effluvia, some of which originating from the subterranean regions of the earth and some from celestial bodies. These effluvia diffused in the air had something in common with the spirits which, according to his collegue Ralph Bathurst and others (Worsley, for instance), pervaded the universe as a sort of anima mundi. Boyle had rejected this Platonic notion in his New Experiments (1660), yet his works illustrate that the investigation of the spirit never disappeared from his agenda. See A. Clericuzio, 'The internal laboratory. The chemical reinterpretation of medical spirits in England (1650-1680)', in Alchemy 
rethinking the object of physics in broader terms. Boyle's natural theology and More's notion of a spiritual extension, but also Locke's inquiries into Puritan theology and pansophic writings, might have all contributed significantly in this regard. The new physica generalis which he introduced both in Scheme 5 and in the Essay was a manifesto against materialism.

The support which physics could afford to theology was apparent to Locke, as it was to Boyle, Newton and other sustainers of a natural theology. The inverse was also true for Locke, as the outline of Theologia of 1694 showed. An attentive study of the Scriptures could disclose the purposiveness of the 'Creation of the material World, of this visible Frame, of Sun, Moon, and Stars, and heavenly Bodies that are over us, and of the Earth we inhabit'. ${ }^{227}$ It revealed that 'there are both animal and spiritual bodies', of which 'the spiritual was not the first but the animal', and that the first man, Adam, was made of 'earthy particles'. ${ }^{228}$ The intelligible truth of the Scriptures, and in particular of Revelation, was the solid ground on which physics could base its inquiries.

Gabriele D’Annunzio University of Chieti-Pescara

and Chemistry in the 16th and 17th Centuries, ed. P. Rattansi and A. Clericuzio (Dordrecht, 1994), 53-58.

${ }^{227}$ John Locke, A Paraphrase and Notes on the Epistles of St. Paul, ed. Arthur W. Wainwright (2 vols., Oxford, 2003), ii, 641n.

${ }^{228}$ Locke, Paraphrase, i, 254. 


\section{Appendices}

Scheme 1

'Adversaria 1661', fos.1-2. MS Film 77 (c. 1670).

\section{$[\mathbf{f} .2 \mathbf{v}]$}

\section{Materia}

Extensio et Numerus

Motus

Universum

\section{Physica sive Corporum Scientia}

$\begin{array}{ll}\text { Coelestia } & \text { Astronomia } \\ \text { Ignis } & \\ \text { Aer } & \text { Meteora } \\ \text { Aqua } & \text { Mare } \\ \text { Terrestria } & \text { Geographia Physica }\end{array}$

\section{Fossilia}

\section{Vegetabilia}

Animalia Insecta. Volatilia Gressilia, natantia

\section{Homo}

Anima

Intellectus volutas passiones quae pertinere etiam possunt ad Theologiam

Corpus humanum Medecina. Anatomia sive hist. partium. Pathologia sive historia affectium, et Therapeutica sive hist. Curationum

$\begin{array}{ll}\text { Sensus } & \text { Objecta sensuum } \\ & \text { Numerus Arithmetica } \\ \text { Quantitas } & \text { Geometria et Arithmetica } \\ & \text { Extensio Geometria } \\ & \text { Motus. Gravitas pondus mechanica } \\ & \text { Colores pictoria et tinctoria } \\ & \text { Soni musica } \\ & \text { Odores } \\ & \text { Sapores Coquinaria } \\ & \text { Tactiles qualitates Calor frigus } \\ & \text { et de his omnibus artes mechanicae }\end{array}$

$* * *$ 


\title{
Scheme 2
}

'Sapientia 72' (MS Locke c. 28, f. 41r-v), f. 41r

\author{
Physica \\ Mundus sive universum \\ Materia Corpus
}

\section{Coelestia}

Astronomia

Ignis

Aer

Aqua

Terra et fossilia >et fossilia Geographia Physica

\section{Vegetabilia}

\section{Animalia}

Anima brutorum

Gressilia, serpentia reptilia insecta natantia volantia volucres

natantia aquatica anphybia

\section{Homo}

Anima

Facultates

Perceptio Imaginatio

Memoria

Intellectus

Voluntas

\section{Corpus humanum Medicina}

Anatomia sive historia partium

Pathologia sive historia affectuum

Therapeutica sive hist. curationum

Sensus Objecta sensuum

Numerus Arithmetica

Extensio Geometria

Motus. Gravitas. pondus mechanica

Colores. Ars pictoria tinctoria etc.

Soni Musica

Odores

Sapores Coquinaria

Tactiles qualitates. Calor frigus

et de his omnibus Artes mechanicae 


\section{A: MS Locke f. 15, pp. 119-120 (crossed out)}

[p. 119]

Adversaria

Cognoscendor $\bar{u}[\mathrm{~m}]$ philosophica i. e. quicquid conducere potest ad notitiam entiū $[\mathrm{m}]$ eorumq[ue] causarum proprietatum effectuum et consequentiarum ut sc eorum habeamus veras claras et destinctas Ideas. Quicquid hujusmodi occurrit destribuendum in capita secundum varias rerū $[\mathrm{m}]$ - Species

[p. 120]

Adversaria Historica physica. sc. proprietates et effectus cor: porum eorumq[ue] qualitatum qui ad usum vel cognitionem maxime spectant destribuenda in capita per Species Bonitas

Agendorum Immitanda

Physica sive artes quae in usū[m] nostrum transferri possunt circa

Cibum potum Medecinam Veterinaria

motum sc. Mechanica sensuum objecta Sensus adjuvandos Chimica res conservandas vel meliorandas haec omnia * pharmaceutica

Species 


\section{B: MS Locke c. 28, f. 50 r-v}

[f. 50r]

Adversaria

Cognoscendorum
In Legendis Authoribus haec mihi praecipue observanda videntur.

philosophica i. e. Quicquid conducere possit ad notitiam entium eorumq[ue] causarum proprietatum effectuum et consequentiarum ut sc: eorum habeamus veras, claras et destinctas Ideas. Quicquid hujusmodi occurrit destribuendum in Capita -

Ethica

secundum varias rerum

Species Physica

[f. 50v]

Adversaria Historica physica. In quibus proprietates et effectus corporum eorumq[ue] qualitatum qui ad usum vel cognitionem maxime spectant destribuendi in capita per Species Bonitas

Agendorum Immitanda

Physica sive artes quae in usum nostrum transferri possunt circa

motum sc.

sensuum objecta Sensus accudendos

Res meliorandas vel conservandas haec omnia per
Cibum

Potum. Vestitum

Medecinam

Veterinaria

Mechanica

Species 


\section{Scheme 3}

(MS Locke f.2, pp. 247-52, Sept. 4 1677)

[p. 248]

Adversaria The first of w[hi]ch is the knowledg of things

their essence \& nature, properties causes \& consequen-

ces of each species w[hi]ch I call philosophi-

ca $\&$ must be divided according to the severall orders \& species of things. And

of these soe far as we have the true notions of things as really they are in their in destinct beings. soe far we advance in reall $\&$ true knowledg. And this improvemt of our understandings Is to be got more by meditation then reading though that also be not to be neglected. And the faculty chiefly exercisd about this the judgmt.

[p. 251, heading Adversaria Immitanda]

$\cdots$

Physica

ubi sive artes circa

Potum

Cibum

Medecinam

Motus ubi Mechanica

Sensuum objecta

[p. 252] There is yet one more w[hi]ch is the knowledg of the natu history of naturall causes $\&$ effects where in it may be convenient in our reading to observe those severall effects propertys of bodys \& the severall effects that severall bodys or their qualitys have one upon another. \& principally to remark those that may contribute either to the improvemt of arts or give light into the nature of things өr w[hi]ch is that w[hi]ch I call about philoso phica w[hi]ch: I conceive to consist in having a true cleare \& destinct Idea of the nature of any thing things or reall beings tsually because we are ignorant of their essence takes in their causes propertys \& effects or as much of them as we can know, \& their in Morall beings their essence \& consequences.

This naturall history I call

Historica physica. referenda secundum species 


\section{C: MS Locke f. 15, pp. 122-23}

[p. 122]

Adversaria

Cognoscendorum i.e.

[p.123]

philosophica sc: quicquid conducere

possit ad notitiam entium eorumq[ue]

causarum, proprietatum effectuum

et consequentiarum ut sc: eorum

habeamus veras claras et destinctas

ideas. quicquid hujusmodi occurrit

destribuendum in Capita secundum

varias rerum Species

Ethica

Physica

Historica physica in quibus

Proprietates et effectus corporum

eorumq[ue] qualitatum. qui ad usum

vel cognitionem maxime spectant

per-

Indicia vel nota bonitatis

Species

cuiusq[ue] rei prout usui nostro

Bonitas

solet inservire

Agendorum

Immitanda

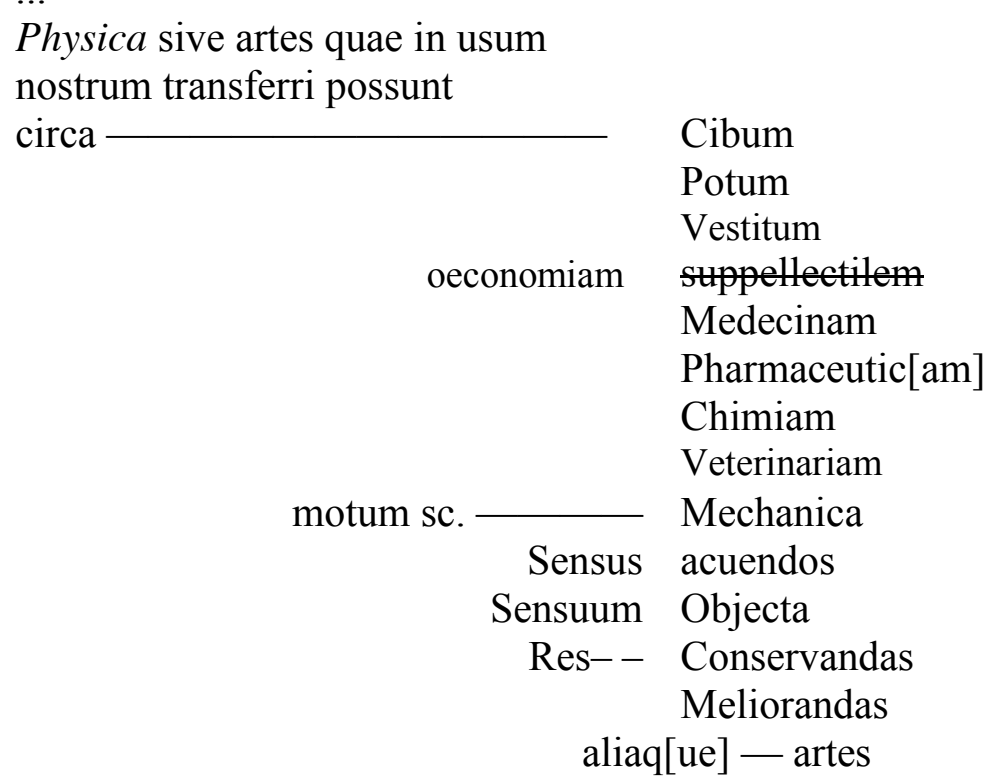




\section{D: MS Locke c. 28, f.51r-v}

[f. 51r]

Adversaria

12 Nov. 77
In legendis Authoribus haec mihi praecipue observanda videntur

$1^{\circ}$ Cognoscendorum Philosophica i.e. Quicquid conducere possit ad notitiam entium philosophicam: Ut sc. / de eorum essentiis causis effectibus veras, claras, et destinctas Ideas habeamus $1^{\circ}$ quae sunt entis in Genere ut Metaphysica, $2^{\circ}$ specierum entis ut Physica / Quicquid huiusmodi occurrit destribuendum in capita secundum $3^{\circ}$ quae pendent ex voluntate hominum ut Ethica [varias rerum Species 3 Ethica

2 Physica

1 Metaphysica

[f.51v] Historica physica $-\quad 1^{\circ}$ in quibus [>notitia corporum eorumq[ue]] proprietates et effectuu[m] corporum eorumg[ue]

qualitatum. quae ad usum vel cognitionem maxime spectant distribuenda in capita per $\longrightarrow$ Species $2^{\circ}$ Notae et signa cuiusq[ue] rei suo in genere bonae et perfectae Bonitas

$3^{\circ}$ Agendorum - 1 Immitanda

$2^{\circ}$ Physica sive artes soler tiam ut quae in usum nostrum rebusq[ue] nostris accomodari

possint circa

Cibum

Potum

Vestitum

Suppellectilem

Medecinam

Pharmaceuticam

Chimiam

Veterinariam

motum ut Mechanicam

Sensuum objecta

Sensus acuendos

Res Conservandas meliorandas

Artes alias 
$3^{\circ}$ Historica physica----- sc. Rerum Incorporeorum

Spiritum

$1^{\circ}$ omnia quae accidunt ultra

nostram atmosphaeram ut

Oupavika

$2^{\circ}$ Quae ecemrment observanda in

nostra atmosphaeria

Meteorica

$3^{\circ}$ In mare fluminibus lacubusq[que]

4 De Terra

Hydrographica

5 In regno sensitivo

Geographica

6 - intellectuali

Animalium

7 Vegetabili

Hominum

8 Subterranea

Vegetabilium

9 quicquid in quolibet horum

praeter solitum na[tur]ae cursum

eccurrit sive prodigium dicas

sive miraculum

Mira

$* * *$ 


\section{Scheme 4}

MS Locke c. 28, pp. 157-58.

[p. 158r]

Physica

Mundus Sive universum

Materia corpus

Vaccuum

Coelum Astronomia Chronologia

Aether

Ignis

Aer Meteora

Aqua Oceanus Fluvij ffontes Thermae Acidulae

Terra Geographia

Fossilia

\section{Homo}

Anima rationalis

Facultates

Perceptio

Imaginatio

Memoria

Intellectus

Voluntas

Corpus humanum Medicina

Anatomia Sive historia partium

Pathologia Sive hist. affectuum

Therapeutica Sive hist. curationum
Sensus objecta sensuum

Numerus Arithmetica

Militaris

Extensio Geometria Architectura

Motus Gravitas Mechanica

Colores pictoria et tinctoria

Lux optica

Colores Ars pictorial et tinctoria

Soni Musica

Odores

Volucres

Aquatica

Amphybia
Civilis

Navalis
Sapores. Coquinaria

[p.158v] Tactiles qualitates. Calor frigus etc. et quae in his occupantur Artes

$* * *$ 


\section{Scheme 5}

MS Locke c. 28, ff. 155-56.

[p. 155r]

\section{Physica}

$1^{\circ}$ Theologia

$2^{\circ} \pi v \varepsilon v \mu \alpha \tau \kappa \kappa n$

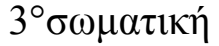

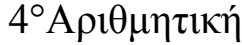

$5^{\circ} \gamma \varepsilon 0 \mu \varepsilon \tau \rho \imath \alpha$

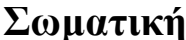

$1^{\circ}$ Y $\rho \alpha v_{0} \lambda \gamma_{1 \alpha}$

$2^{\circ}$ A

$3^{\circ}$ Atmosphaerica in qua meteorologia

$4^{\circ}$ Geographia Hydrographia

$5^{\circ}$ Hydrographia Geographia

$6^{\circ}$ Fossilia Metalla, Semimetalla, Sales Succi concreti, Lapides, Boli

$7^{\circ}$ Vegetabilia Arbores, Fructices, Herba

$8^{\circ}$ Mineralia Fossilia Zooroyra avtonata

[p. $155 \mathrm{v}]$

8 Animalia

Zoodorta Animalia

$1^{\circ}$ Homo. Reptilia. Aquatilia

$2^{\circ}$ Quadrupides vel gressilia Aquatilia Voulcres

$3^{\circ}$ Volatilia volucres Volucres Reptilia

$4^{\circ}$ Natantia Aquatilia Quadrupides.

$5^{\circ}$ Reptilia Homo

\section{Vegetabilia}

10 Arbores

$2^{\circ}$ Fructices

$3^{\circ}$ Herba

\section{Mineralia Fossilia}

$1^{\circ}$ Metalla

$2^{\circ}$ Sales Semi metalla vel mineralia

$3^{\circ}$ Sales

$4^{\circ}$ Succi concr[eti]

$5^{\circ}$ Lapides

$6^{\circ}$ Terrae Boli

1 Motus

$2^{\circ}$ Visus Lux Colores prospectiva gotica

tinctoria

$3^{\circ}$ Auditus Soni

$4^{\circ}$ Gustus Sapores 
$5^{\circ}$ Olfactus odores

Medicina

Veterinaria

Mechanica

$* * *$ 